\title{
Seedling growth and morphology of three oak species along field resource gradients and seed mass variation: a seedling age-dependent response
}

\author{
Ignacio M. Pérez-Ramos, Lorena Gómez-Aparicio, Rafael Villar, Luis V. García \& \\ Teodoro Marañón
}

\begin{abstract}
Question: What is the relative importance of seed mass and abiotic factors in species-specific seedling growth and morphology during the first and the second growing season? How do oak species respond along gradients of these factors?

Location: Mediterranean oak forest in southern Spain.

Methods: We analysed seedling growth components and morphology of three co-occurring Quercus species (two deciduous and one evergreen). Oak seeds with a wide variety of sizes were sown along broad gradients of abiotic conditions. Intra- and inter-specific differences were evaluated by calibrating maximum likelihood estimators of seedling growth during the first two years of life.

Results: We found multiple resources and conditions affecting seedling morphology and biomass allocation. However, the integrative variables of seedling growth - total aboveground biomass and relative growth rate (RGR) - were affected by two main factors: seed mass and light conditions. The relative contribution of these two factors depended strongly on seedling age. Seed mass explained most of the growth and morphological variables during the first year, while light conditions were the best predictor in the second growing season. In contrast, soil factors did not play an important role in seedling growth. We found some evidence of regeneration niche partitioning between oak species along the
\end{abstract}

Pérez-Ramos, I.M. (corresponding author, Ignacio. PEREZ-RAMOS@cefe.cnrs.fr), Gómez-Aparicio, L. (lorenag@inase.csic.es), García, L.V. (ventura@cica.es) \& Marañón, T. (teodoro@irnase.csic.es): Instituto de Recursos Naturales y Agrobiología de Sevilla, CSIC, P.O. Box 1052, Sevilla 41080, Spain.

Villar, R. (bv1vimor@uco.es): Área de Ecología, Facultad de Ciencias, Universidad de Córdoba, 14071 Córdoba, Spain.

Gómez-Aparicio L.: Present address-Instituto Nacional de Investigación y Tecnología Agraria y Alimentaria, INIA, Crta. de la Coruña, km. 7, 5 28040, Madrid, Spain. light gradient, a reflection of their distribution patterns as adults at the study site.

Conclusions: We conclude that inter-specific differences in seedling growth, arising from seed size variability and microsite heterogeneity, could be of paramount importance in oak species niche segregation, driving stand dynamics and composition along environmental gradients.

Keywords: Leaf life-span; Mediterranean forest; Quercus canariensis; Quercus pyrenaica; Quercus suber; Regeneration niche; Relative growth rate.

\section{Introduction}

The seedling stage is crucial for plant population dynamics due to its higher vulnerability to environmental constraints in comparison with seed and adult stages (Harper 1977; Silvertown \& Charlesworth 2001). Studies on plant growth during this demographic phase and how resources affect this process are critical for understanding tree recruitment patterns (Poorter 2001; Villar et al. 2008; Gómez-Aparicio et al. 2008), which in turn largely drive forest composition and dynamics (e.g. Pacala et al. 1996; Zavala et al. 2000; Kobe 2006).

Most studies on seedling growth components have been carried out under controlled conditions and have focused on the effect of a low number of factors (e.g. Grubb et al. 1996; Walters \& Reich 2000; Espelta et al. 2005; Quero et al. 2006, 2008; Sánchez-Gómez et al. 2006). Although greenhouse experiments provide very valuable information, they do not allow a representation of the complex scenario to which plants are exposed in nature. Natural conditions where plant species regenerate constitute a multidimensional space where many abiotic and biotic factors act simultaneously and interactively (Ibañez \& Schupp 2001; Gómez 2004; Puerta-Piñero et al. 2007). However, there are very few published examples identifying the main factors - and their interactions - that drive seedling growth along wide, natural environmental gradients. 
In natural conditions, the amount of light intercepted for photosynthesis is one of the most important environmental factors affecting seedling growth in the understorey, and plants acclimate to this resource through morphological and physiological changes (Poorter 2001; Quero et al. 2008). Plant species may respond not only to light availability, but also to its spectral quality. Many plants are sensitive to changes in the red:far-red light ratio (R:FR), which can be considered a signal of shading and proximity to other plants (Gilbert et al. 1995; Aphalo \& Lehto 2001), and usually respond to this factor by modifying certain morphological and physiological traits as mechanisms of shade avoidance (Ammer 2003; Tegelberg et al. 2004).

The variation in soil resource availability, mainly of water and nutrients, can also modulate seedling and sapling performance (Kobe 2006). The importance of soil water for seedling growth has been well documented for Mediterranean plants (e.g. Di Castri et al. 1981; Blondel \& Aronson 1999; Valladares \& Sánchez-Gómez 2006). However, scant information is available on how growth and morphology of Mediterranean tree species vary along natural gradients of nutrients.

In addition to external abiotic factors, seedling growth can vary according to some intrinsic traits of the plant species, such as seed mass and leaf lifespan. On one hand, seed mass represents the amount of reserves provided for the young plant during its early life, being one of the main characters influencing seedling early growth (Long \& Jones 1996; Quero et al. 2007; Turnbull et al. 2008). On the other hand, seedlings with short-lived leaves (deciduous species) tend to show a higher efficiency for assimilation of light and $\mathrm{CO}_{2}$, and thus grow faster than related evergreen species (Reich et al. 1992; Cornelissen et al. 1998; Antúnez et al. 2001; Wright et al. 2004). Leaf lifespan can therefore be related to species habitat and distribution patterns across landscapes (Reich et al. 1992; Ruíz-Robleto \& Villar 2005).

The changes in seedling biomass through time i.e. the relative growth rate (RGR) - can be broken down into a morphological component, the leaf area ratio (LAR), which indicates the plant investment in leaves, and a physiological component, the net assimilation rate (NAR) or plant mass increment per leaf area. In general, the morphological component (LAR) is the biggest contributor to RGR variation in tree species (Reich et al. 1992; Huante et al. 1995; Cornelissen et al. 1998; Antúnez et al. 2001). However, most of these studies are greenhouse experiments that usually use limiting light conditions. The few studies that have explored these relationships under field conditions suggest that the physiological component (NAR) also plays an important role, especially in high light environments (Poorter 1999; Shipley 2002).

This study is part of a general research programme on the regeneration ecology of three cooccurring Quercus species - two deciduous (Quercus canariensis Willd. and Quercus pyrenaica Willd.) and one evergreen (Quercus suber L.) - that dominate the tree canopy in forests of southern Spain. In the selected study area (Aljibe Mountains), the studied oak species segregate along environmental gradients of soil moisture and canopy cover. Thus, $Q$. suber tends to dominate in habitats with a lower availability of water and nutrients, where the overstorey canopy is usually sparse (Pérez-Ramos 2007). In contrast, $Q$. canariensis is more abundant in moister habitats, where the overstorey canopy is denser (Urbieta et al. 2008b). Q. pyrenaica is less frequent in the study area, and restricted to scarce populations at higher altitudes $(>900 \mathrm{~m})$. We hypothesise that differences in the adult distribution of these species should be reflected as differential responses to environmental factors at the seedling stage: for example, $Q$. canariensis seedlings being more shade-tolerant and waterdemanding than $Q$. suber seedlings.

These three oak species, which are protected by a European Union Directive (Habitat Directive 92/ 43EEC), frequently exhibit problems of natural regeneration (Pérez-Ramos 2007). In previous studies, we explored the effects of seed size and vegetation cover on seed removal (Pérez-Ramos et al. 2008a), and the effects of soil conditions and light availability on seed germination, seedling survival and plant biomass (Gómez-Aparicio et al. 2008; Urbieta et al. 2008a). Specifically, in this paper we analyse in detail seedling growth (both RGR and its two growth components) and morphology in a field experiment by sowing seeds of the three oak species along wide gradients of abiotic factors, with a broad range of seed mass for each species. All measurements were made during the first 2 years of seedling life, which enabled us to evaluate whether species responses along resource gradients changed depending on the time scale. Most previous studies have focused on first-year seedlings, but the influence of environment is expected to change drastically with time, since seed reserves are mainly depleted during the first months of seedling life (Quero et al. 2007).

The main aims of this study are (i) to examine the relative importance of seed mass and abiotic factors (light, soil water and nutrient content, soil texture and soil compaction) on species-specific seedling growth and morphology; (ii) to test whether seedling growth 
and morphology are more dependent on seed mass during the first year, while they are more affected by environmental conditions during the second growing season; (iii) to explore the intrinsic causes of variation in growth rates (LAR versus NAR); (iv) to investigate whether oak species or functional groups (deciduous versus evergreen) respond differently along gradients of these factors; and (v) to infer whether their distribution patterns across landscapes are a reflection of inter-specific differences in seedling response to environment, and to discuss the ecological implications of all these findings for forest stand dynamics and species coexistence.

\section{Methods}

\section{Study site and experimental design}

The study was conducted in La Sauceda forest (530 $\mathrm{m}$ above sea level, $36^{\circ} 31^{\prime} 54^{\prime \prime} \mathrm{N}, 5^{\circ} 34^{\prime} 29^{\prime \prime} \mathrm{W}$ ), located in the mixed oak forests of the Aljibe Mountains, near the Strait of Gibraltar, in southern Spain (for a detailed description of the experimental site, see Pérez-Ramos et al. 2008b; Quilchano et al. 2008). The climate is sub-humid Mediterranean, with mild wet winters alternating with hot dry summers. Annual mean temperature is $17^{\circ} \mathrm{C}$, and annual mean rainfall is $1265 \mathrm{~mm}$ (based on 1985-2004 yearly data from La Sauceda meteorological station). The overstorey canopy of this forest is co-dominated by the evergreen $Q$. suber and the deciduous $Q$. canariensis, whereas the deciduous $Q$. pyrenaica is present only in scarce populations at higher altitudes $(>900 \mathrm{~m})$.

Acorns of $Q$. suber and $Q$. canariensis were collected from several trees (at least ten of each species) in the surroundings of the study area during the fruiting season (October-December) of 2003. Acorns of $Q$. pyrenaica (with scarce seed production in the Aljibe Mountains) were brought from stands in the Sierra Morena (an inland area also in southern Spain). We selected healthy, normal-sized acorns and discarded those infected by moth or beetle larvae using a flotation method (Gribko \& Jones 1995). Selected acorns were individually weighed to the nearest $0.01 \mathrm{~g}$ and stored on a moist substrate at $2-4^{\circ} \mathrm{C}$ until used in the experiment. Mean $\pm \mathrm{SD}$ (standard deviation) acorn fresh weight was $4.36 \pm 1.63 \mathrm{~g}$ for $Q$. suber, $4.48 \pm 1.38 \mathrm{~g}$ for $Q$. canariensis and $5.56 \pm 1.04 \mathrm{~g}$ for $Q$. pyrenaica. We used acorn fresh weight as a surrogate for dry seed mass, justified by their high correlation (with $R^{2}$ values ranging from 0.93 to 0.99, Quero et al. 2007). In December 2003, seeds from the three species were sown horizontally, 1-3-cm deep in the mineral soil, simulating biotic acorn dispersal by European jays (Kollmann \& Schill 1996), rodents (Gómez et al. 2008) or dung beetles (Pérez-Ramos et al. 2007). Seeds were randomly distributed among 60 experimental units (with a size of about $2 \mathrm{~m}^{2}$ and a minimum distance of $10 \mathrm{~m}$ between them), which spanned a wide, continuous gradient of soil conditions and light availability, from open habitats (up to $90 \%$ full sun) to deeper shade under shrubs and trees (down to $10 \%$ full sun). Ten acorns of $Q$. suber, ten acorns of $Q$. canariensis, and eight acorns of $Q$. pyrenaica were sown in each unit, protected by wire cages $(25 \times 25 \times 25 \mathrm{~cm}, 1.3-\mathrm{cm}$ mesh size) to exclude seed predators.

\section{Characterisation of abiotic factors}

Aboveground (light availability and R:FR) and belowground (soil water and nutrient content, soil compaction and soil $\mathrm{pH}$ ) factors were quantified in each of the 60 experimental units; a list of the 17 abiotic factors measured is given in Table 1.

Light availability was estimated by means of hemispherical canopy photography. Photographs were taken at the seedling level in the centre of each experimental unit, using a horizontally levelled digital camera (Coolpix 4500, Nikon, Tokyo, Japan) with a fish-eye lens and $180^{\circ}$ field of view (FCE8, Nikon). Photographs were taken before dawn, after sunset, or at other times of day when the sun was blocked by clouds, ensuring homogeneous condi-

Table 1. Environmental variability of the 60 experimental microsites. Mean, standard deviation and range of the 17 abiotic factors considered in the study.

\begin{tabular}{|c|c|c|}
\hline Abiotic Factor & Mean $\pm \mathrm{SD}$ & Range \\
\hline Light availability $-\mathrm{GSF}-(\%)$ & $31.7 \pm 23.7$ & $8.0-88.9$ \\
\hline Light spectral quality $-\mathrm{R}: \mathrm{FR}-$ & $0.64 \pm 0.34$ & $0.09-1.30$ \\
\hline \multicolumn{3}{|c|}{ Soil volumetric water content - VWC $-(\%)$} \\
\hline Minimum & $9.3 \pm 2.8$ & $5.0-17.5$ \\
\hline Maximum & $56.3 \pm 22.5$ & $27.0-90.7$ \\
\hline Mean & $38.3 \pm 14.0$ & $20.0-79.0$ \\
\hline \multicolumn{3}{|l|}{ Soil compaction $(\mathrm{MPa})$} \\
\hline Maximum & $4.63 \pm 1.33$ & $2.10-8.19$ \\
\hline Superficial & $1.89 \pm 0.62$ & $0.96-3.36$ \\
\hline Soil depth $(\mathrm{cm})$ & $35.68 \pm 9.16$ & $13.50-49.00$ \\
\hline Soil pH & $6.22 \pm 0.58$ & $5.39-8.30$ \\
\hline Soil clay $(\%)$ & $36.6 \pm 10.8$ & $13.7-62.6$ \\
\hline Soil organic matter $-\mathrm{OM}-(\%)$ & $10.5 \pm 3.7$ & $4.8-20.6$ \\
\hline \multicolumn{3}{|l|}{ Soil nutrients } \\
\hline Nitrogen $(\%)$ & $0.33 \pm 0.12$ & $0.12-0.75$ \\
\hline Ammonium $\left(\mathrm{mg} \mathrm{kg}^{-1}\right)$ & $30.7 \pm 29.1$ & $6.8-160.9$ \\
\hline Phosphorus ( $\mathrm{mg} \mathrm{kg}^{-1}$ ) & $1.9 \pm 1.8$ & $0.2-8.9$ \\
\hline Calcium $\left(\mathrm{mg} \mathrm{kg}^{-1}\right)$ & $2903 \pm 1749$ & $477-7925$ \\
\hline Potassium $\left(\mathrm{mg} \mathrm{kg}^{-1}\right)$ & $191 \pm 69$ & $89-419$ \\
\hline Magnesium $\left(\mathrm{mg} \mathrm{kg}^{-1}\right)$ & $261 \pm 100$ & $69-530$ \\
\hline
\end{tabular}


tions of illumination at the understorey and a correct contrast between canopy and sky. We used Hemiview Canopy Analysis software (Delta-T Devices Ltd. 1999, v. 2.1) to analyse the images and calculate the Global Site Factor (GSF), which represents the fraction of total radiation above the canopy that penetrates below the canopy (Anderson 1964). Spectral quality of light (R:FR) was measured at each experimental unit using an SKR 110 sensor (Skye Instruments Llandrindod Wells, UK). Measurements of R:FR were taken around midday $(11.00-13.00)$ on a sunny day to avoid errors derived from variations in sun height and cloud cover.

Soil volumetric water content (VWC) was measured using a time-domain reflectometer (TDR, Campbell Scientific Inc., Logan, UT, USA) with 12$\mathrm{cm}$ depth rods. Measurements were taken at each experimental unit (four readings per unit) every 2 months (from January until September) in order to characterise soil moisture during wet-dry periods. For each experimental unit, we calculated minimum, maximum and mean VWC values.

Soil compaction was estimated using a penetrometer (Penetrologger, Eijkelkamp Agriserch Equipment, Giesbeek, The Netherlands), which provides a value of resistance to soil penetration at every $\mathrm{cm}$ in depth. Two measurements were taken in early spring (March 2005) per experimental unit in order to characterise the soil profile to $60-\mathrm{cm}$ depth. From these profiles, we derived three variables that can affect rooting penetration and, consequently, seedling growth: maximum soil resistance in the profile (maximum soil compaction, MPa), superficial soil resistance (superficial soil compaction, mean value of the upper $20 \mathrm{~cm}$ of soil), and maximum depth at which soil resistance was measured, which provides an estimation of soil depth $(\mathrm{cm})$.

To analyse soil physico-chemical properties, we sampled the upper $20 \mathrm{~cm}$ of the soil using an auger ( $3 \mathrm{~cm}$ in diameter) at 3-7 points located inside each experimental unit, and mixed them to produce one composite soil sample per unit. Samples were dried, crushed and sieved, and the $<2-\mathrm{mm}$ fraction was analysed for standard chemical and physical properties (Sparks 1996). Nine soil properties were determined: acidity (with a $\mathrm{pH}$ meter), total organic matter $\left(\mathrm{OM}\right.$, by calcination at $\left.540^{\circ} \mathrm{C}\right)$, available phosphorus (using the Bray-Kurtz method), total nitrogen (using a Kjeldahl digestion and distillation-titration of the produced ammonium), ammonium-N (extracted with $\mathrm{KCl} 2 \mathrm{~N}$ and determined by distillation-titration), available calcium, magnesium and potassium (extracted with ammonium acetate $1 \mathrm{~N}$ and determined by atomic emission spectroscopy) and percentages of sand, silt and clay (using the Bouyoucos hydrometer method). Of the three variables related to soil particle size distribution, only percentage clay was used in the statistical analyses as a representative measurement of textural characteristics.

\section{Seedling growth and morphology measurements}

From the total number of seedlings emerged in the different experimental units, a sample was randomly selected (one seedling per species for each available unit, to avoid problems of pseudo-replication) in order to span a broad range of soil resources and light availability. The total number of marked and measured seedlings was 56 for $Q$. canariensis, 47 for $Q$. pyrenaica and 56 for $Q$. suber during the first growing season, and had to be reduced to 36 for $Q$. canariensis, 29 for $Q$. pyrenaica and 36 for $Q$. suber during the second growing season due to high seedling mortality. Thus, mean survival rates after 2 years were $28 \%$ for $Q$. canariensis, $14 \%$ for $Q$. pyrenaica and $11 \%$ for $Q$. suber (Gómez-Aparicio et al. 2008). For each seedling, non-destructive measurements in stems and leaves were taken repeatedly over time. Length and diameter at three marked positions (at the base, at $4 \mathrm{~cm}$ from the base, and at the top) were measured for stems and branches. Diameters were taken in two perpendicular directions, using a caliper with precision of $0.001 \mathrm{~cm}$. The number of leaves was counted and measurements of length and width were recorded for each leaf. To estimate the RGR of the aboveground part of the seedling $\left(\mathrm{RGR}_{\mathrm{a}}\right)$, these non-destructive measurements were taken at the beginning (April-May 2004) and end (June 2004) of the growing season, until there was no longer any evidence of seedling growth. Surviving marked seedlings were re-measured 12 months later (June 2005) in order to estimate $\mathrm{RGR}_{\mathrm{a}}$ during the second growing season.

To estimate stem biomass and leaf area from the non-destructive measurements, additional seedlings were harvested and measured in a representative sample of the same experimental units. The number of selected seedlings for destructive measurements ranged between 15 and 20 per species at each sampling date (at the beginning and end of the growing season). Once the samples were in the laboratory, all the non-destructive measurements described above were taken, and then each seedling was separated into leaf and stem fractions. Each fraction was oven-dried at $60^{\circ} \mathrm{C}$ for $48 \mathrm{~h}$ and weighed to the nearest $0.0001 \mathrm{~g}$. Linear regressions between volume and dry weight of the stem were calculated per species and sampling 
date $\left(R^{2}>0.86\right)$ using the harvested seedlings. These regressions were used to estimate stem biomass from the non-destructive measurements.

To calculate total leaf area per seedling, all fresh leaves were scanned and their areas measured using an image analysis programme (Image Pro-plus 4.5, Media Cybernetic Inc., USA). An allometric relationship per species and growing season was established between leaf area and individual measurements of leaf length and width $\left(R^{2}>0.97\right)$, and applied to estimate total leaf area for each seedling based on individual non-destructive leaf measurements taken in the field. In addition, relationships between total leaf area and leaf dry weight in harvested seedlings were used to calculate specific leaf area (SLA) values per species and sampling date. The ratio between the estimated total leaf area and SLA mean values provided good estimates of leaf biomass for the seedlings monitored in the field.

The sum of the leaf and stem biomass provided an estimate of the total aboveground biomass for each seedling monitored in the experiment.

The aboveground relative growth rate $\left(\mathrm{RGR}_{\mathrm{a}}\right)$ was calculated for each seedling as $\mathrm{RGR}=\left(\ln M_{1}-\right.$ $\left.\ln M_{0}\right) / t$, in which $M_{0}$ and $M_{1}$ are the aboveground biomass values at the beginning and end of each growing season, respectively, and $t$ is the time interval between the two dates. For the first year, we calculated the seasonal growth $\left(\mathrm{RGR}_{\mathrm{a}}\right.$ in $\left.\mathrm{g} \cdot \mathrm{g}^{-1} \cdot \mathrm{d}^{-1}\right)$ during 66 days (from April to June 2004, for $Q$. $c a$ nariensis and $Q$. suber seedlings) or 31 days (from May to June, for $Q$. pyrenaica, due to its later seedling emergence). For the second year, we calculated the annual growth $\left(\mathrm{RGR}_{\mathrm{a}}\right.$ in $\left.\mathrm{g} \cdot \mathrm{g}^{-1} \cdot \mathrm{y}^{-1}\right)$ between June 2004 and June 2005. The RGR $\mathrm{a}_{\mathrm{a}}$ was separated into its two main components: the leaf area ratio $\left(\mathrm{LAR}_{\mathrm{a}}\right.$, leaf area per unit aboveground biomass, $\mathrm{cm}^{2}$ $\mathrm{g}^{-1}$ ) and the NAR (net aboveground biomass growth per unit leaf area, $\mathrm{g} \cdot \mathrm{cm}^{2} \cdot \mathrm{d}^{-1}$ or $\left.\mathrm{g} \cdot \mathrm{cm}^{2} \cdot \mathrm{y}^{-1}\right)$, which were calculated according to formulas given by Hunt (1978). In addition, we calculated other morphological variables such as the specific stem length (SSL, stem length per unit stem biomass, $\mathrm{cm} \mathrm{g}^{-1}$ ), or total leaf area $\left(\mathrm{cm}^{2}\right)$. Finally, the leaf mass ratio $\left(\mathrm{LMR}_{\mathrm{a}}\right.$, proportion of aboveground biomass assigned to leaves) was included in the statistical analyses as a representative measurement of biomass allocation.

\section{Data analyses}

\section{Analyses of abiotic factors}

Variation trends of the 17 abiotic variables were explored using two complementary approaches: first, a principal components analysis (PCA) on all abiotic factors, and second, Pearson's correlation analyses among the main variables defining each PCA axis. Previously, all variables were standardised and, if necessary, log-transformed to fulfill assumptions of normality and homoscedasticity. Normality was tested using the Shapiro-Wilk test. These analyses were carried out using Statistica (v. 6, StatSoft Inc., 2001).

\section{Models of seedling growth}

We fitted linear and non-linear models of seedling growth for each oak species using maximum likelihood techniques. The different variables related to seedling growth were modelled independently as functions of seed mass and each of the 17 abiotic factors considered in the study (Table 1). We tested three alternative functions (linear, exponential and Michaelis-Menten), which cover a wide range of possible forms (see equations in Appendix S1). We first tested models for each factor and function independently, and the best of the three models was compared with a fourth model (the null model) that assumes no effect of any factor. Second, to test for joint limitation (i.e. more than one factor being limiting at once), we fitted bivariate and trivariate models using those factors that had an effect on different variables of seedling growth when evaluated singly. We tried alternative models in which the second and the third abiotic factor were added either additively or multiplicatively. Models including more than three factors were not considered due to their lower empirical support compared with the others. In total, more than 4000 different models were individually run for this study. This modelling approach is suitable to identify strategic axes along which species differentiate (e.g. Pacala et al. 1996; Kobe 1999, 2006; Gómez-Aparicio et al. 2008; Urbieta et al. 2008a).

\section{Parameter estimation and model comparison}

Models were parameterised with maximum likelihood (Edwards 1992), using a simulating annealing algorithm. Based on exploratory analyses, we assumed a Poisson distribution for the response variable "number of leaves" and a normal distribution for the rest of the seedling growth variables. The alternative models were compared using the Akaike Information Criterion corrected for small sample sizes $\left(\mathrm{AIC}_{\mathrm{c}}\right)$ (Burnham \& Anderson 2002) the lower the AIC value, the better the model. The absolute magnitude of the differences in $\mathrm{AIC}_{\mathrm{c}}$ $(\triangle \mathrm{AIC})$ between alternative models provides an 

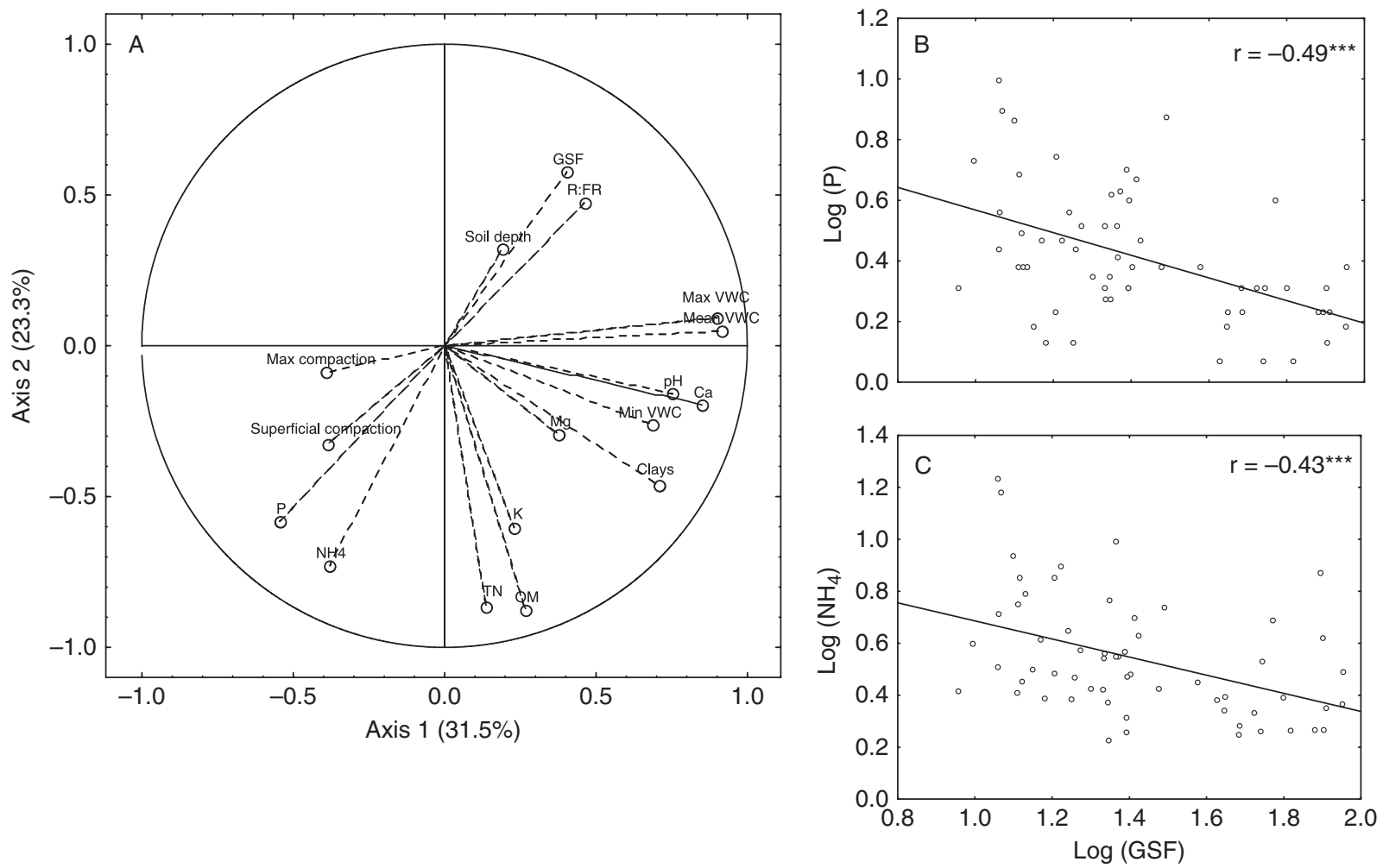

Fig. 1. Projection of the 17 measured abiotic variables on the plane defined by the two main axes resulting from the Principal Components Analysis (a). Relationships between light availability (GSF) and the two main key nutrients, phosphorus (b) and ammonium (c).

objective measurement of the strength of empirical support for the competing models. Models with $\triangle$ AIC between 0 and 2 were considered to have equivalent and substantial empirical support (Burnham \& Anderson 2002). We used asymptotic twounit support intervals to assess the strength of evidence for individual maximum likelihood parameter estimates (Edwards 1992). The $R^{2}$ of the regression of observed versus predicted was used as a measurement of goodness of fit of each alternative model. All models were implemented using the likelihood package version 1.1 for $\mathrm{R}$ and software written specifically for this study in R v 2.5.0 ( $R$ Development Core Team 2006).

\section{Results}

\section{Variation in abiotic factors}

The high environmental heterogeneity of environmental conditions and resource availability was reflected in the wide variation shown by the 17 variables measured for the 60 microsites where oak seedlings grew (Table 1). For example, light availability (GSF) varied between $8 \%$ and $89 \%$, mean soil water content ranged from $20 \%$ to $79 \%$, superficial soil compaction from 0.96 to $3.36 \mathrm{MPa}$, soil ammonium from 7 to $161 \mathrm{mg} \mathrm{kg}^{-1}$ and soil phosphorus from 0.2 to $9 \mathrm{mg} \mathrm{kg}^{-1}$.

Under field conditions, abiotic factors were correlated - either positively or negatively - as shown by the PCA results (Fig. 1a). The first axis $(31.5 \%$ of the total variance) represented a combined gradient of soil moisture and calcium availability, while the second axis $(23.3 \%$ of variance) was clearly defined by a light availability gradient joined to a decreasing soil nutrient content (mainly ammonium and phosphorus). Therefore, soils in open microsites were poorer in nutrients, especially phosphorus $\left(r_{\log G S F}-\log \mathrm{P}=\right.$ $-0.49 ; \quad P<0.001 ; \quad$ Fig. $1 \mathrm{~b})$ and ammonium $\left(r_{\log G S F}-\log \mathrm{NH}_{4}=-0.43 ; \quad P<0.001 ; \quad\right.$ Fig. $\left.1 \mathrm{c}\right)$, the two key resources being highly correlated $\left(r_{\log \mathrm{P}-\log \mathrm{NH}_{4}}=0.76 ; P<0.001\right)$. In addition, soils in moister microsites were more clayey $(r=0.5$; $P<0.001)$, more basic $(r=0.64 ; P<0.001)$ and richer in calcium $(r=0.74 ; P<0.001)$. 


\section{Factors affecting seedling growth and morphology}

In general, there was a wide variation within and between species with regard to seedling growth (Table 2). Light conditions (both light availability and spectral quality) and seed mass were the main factors explaining seedling growth, but their relative importance varied depending on seedling age. The seed mass effect was more evident in the first growing season than in the second, this factor appearing as one of the best predictors in $68 \%$ and $35 \%$ of the 27 modelled variables (nine per species) for the first and the second year, respectively (Tables 3 and 4). In contrast, factors related to light conditions were better represented within the best models for the second growing season $(86 \%$ of the modelled variables) than for the first (56\%; Tables 3 and 4$)$. Several soil variables, such as compaction, $\mathrm{pH}$, water content, and nutrient content (phosphorus and nitrogen), were also good predictors of certain morphological variables, with a similar relative contribution for the 2 years of seedling life (Tables 3 and 4). However, none of them had an important effect on the integrative variables of seedling growth (total aboveground biomass and $\mathrm{RGR}_{\mathrm{a}}$, Tables 3 and 4).

\section{First-year seedlings}

The average aboveground total biomass was much lower for $Q$. pyrenaica than for $Q$. suber and Q. canariensis (support intervals for the intercept $a$ parameter - in the null models overlapped for these two latter species, see Table 2 and Appendix S2). Seed mass was the best predictor of aboveground biomass, but the functional relationship between the two variables differed for the three species (linear for $Q$. canariensis, exponential for $Q$. pyrenaica, and Michaelis-Menten for $Q$. suber; Fig. 2a).

The $\mathrm{RGR}_{\mathrm{a}}$ was similar for the three species (Table 2), but inter-specific differences appeared along gradients of seed mass and R:FR. Along a gradient of seed mass, $Q$. suber was exceeded by the two deciduous species only when seedlings arose from bigger seeds (Fig. 2b). Along a gradient of light quality, $Q$. pyrenaica and $Q$. suber showed a higher $\mathrm{RGR}_{\mathrm{a}}$ than $Q$. canariensis for low values of R:FR, whereas the opposite occurred for high values of R:FR (Fig. 2c). For the first two species, $\mathrm{RGR}_{\mathrm{a}}$ decreased linearly with R:FR, but no effect was found for Q. canariensis (Fig. 2c).

For the three oak species, total aboveground biomass was explained by the variation in $\mathrm{RGR}_{\mathrm{a}}$ (Table 4). In all cases, $R_{G R}$ depended strongly on $\mathrm{NAR}_{\mathrm{a}}$, whereas the influence of $\mathrm{LAR}_{\mathrm{a}}$ was evident only in the case of $Q$. suber (Fig. 3). As a result, the total aboveground biomass of the seedlings was mainly determined by NAR $_{a}$ (Table 5).

Light variables were the best predictors for biomass allocation of the three species. Leaf mass ratio $\left(\mathrm{LMR}_{\mathrm{a}}\right)$ increased with GSF for $Q$. suber (linearly) and $Q$. canariensis (Michaelis-Menten function). In the case of $Q$. pyrenaica, $\mathrm{LMR}_{\mathrm{a}}$ increased linearly with R:FR and decreased with soil $\mathrm{pH}$ (Table 3).

The three species showed marked differences in average stem height $-Q$. suber seedlings being the tallest, followed by $Q$. canariensis and finally by $Q$. pyrenaica (the support intervals did not overlap for the $a$ parameter in the null models, Appendix S2). The three species had a high plasticity of stem elongation, with seed mass and light conditions (GSF or R:FR) again being the main predictor variables (Table 3). Stem height increased with seed mass (linearly for $Q$. canariensis and exponentially for $Q$. suber) and decreased with GSF or R:FR, depending on the oak species (Table 3). There was also evidence of a negative effect of superficial soil compaction on stem height in the case of $Q$. canariensis (Table 3).

Seed mass and light conditions were also the main factors influencing the variation of other morphological variables (Table 3). Larger seeds produced seedlings with a higher total leaf area, a higher number of leaves and lower values of $L_{A R}$ and SSL (Table 3). Regarding light conditions, higher values of GSF and/or R:FR induced oak seedlings with a higher number of leaves and lower values of $\mathrm{LAR}_{\mathrm{a}}$ and SSL (Table 3). The inclusion of several soil variables into multivariate models (bivariate or trivariate) provided the strongest empirical support for certain morphological variables. For example, a higher soil compaction reduced linearly the total leaf area (for $Q$. canariensis) and exponentially the number of leaves (for $Q$. canariensis and $Q$. suber); in the case of $Q$. canariensis, the number of leaves increased exponentially with soil depth. Soils with a higher nitrogen content (total or ammonium) favoured the development of seedlings with higher values of SSL (for $Q$. canariensis) and $\mathrm{LAR}_{\mathrm{a}}$ (for $Q$. suber). Finally, maximum soil moisture was correlated negatively with other morphological and physiological variables, such as SSL or $\mathrm{NAR}_{\mathrm{a}}$, in the case of Q. canariensis (Table 3).

\section{Second-year seedlings}

After two growing seasons, the average aboveground biomass remained much lower for $Q$. 


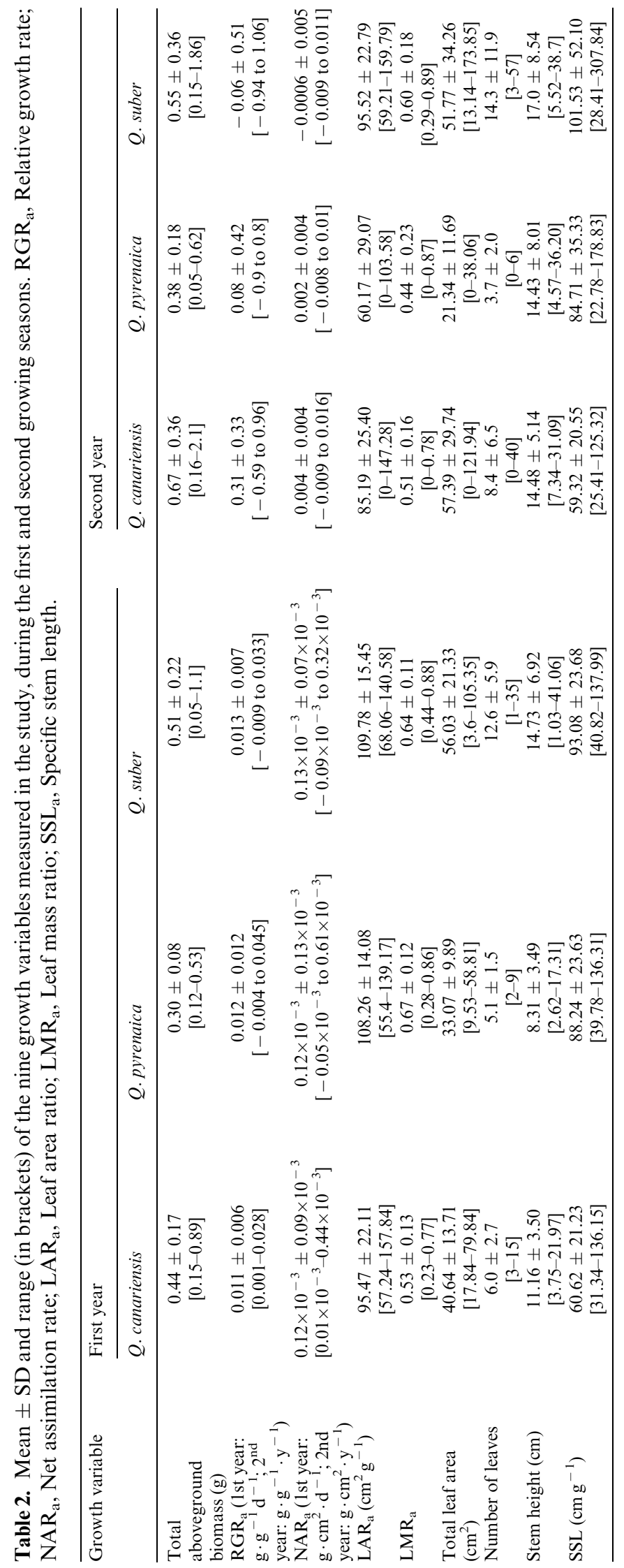


Table 3. Summary of the models analysing the response of first-year seedling growth to seed mass and abiotic factors. Differences in $\mathrm{AIC}_{\mathrm{c}}(\triangle \mathrm{AIC})$ between alternative models represent an objective measure of the strength of empirical support for each model. Only the models with the best empirical support (lowest AIC) are shown. Additive interactions between two or three factors are noted as $(+)$ and multiplicative as $\left(^{*}\right)$. The sign of the relationship (positive or negative) between response variables and the selected predictors is also indicated. Functional Forms (FF): LIN, Linear model; EXP, Exponential model; MM, Michaelis-Menten model; NULL, Null model.

\begin{tabular}{|c|c|c|c|c|c|c|}
\hline $\begin{array}{l}\text { Species } \\
\text { Sp }\end{array}$ & Growth variable & Predictors & FF & Relation & $R^{2}$ & $\Delta \mathrm{AIC}$ \\
\hline \multirow[t]{13}{*}{ Q. canariensis } & \multirow[t]{2}{*}{ Total aboveground biomass } & \multirow[t]{2}{*}{ Seed mass } & LIN & \multirow[t]{2}{*}{+} & \multirow[t]{2}{*}{0.357} & 0.000 \\
\hline & & & NULL & & & 22.497 \\
\hline & \multirow[t]{2}{*}{$\mathrm{RGR}_{\mathrm{a}}$} & \multirow[t]{2}{*}{ Seed mass } & LIN & \multirow[t]{2}{*}{+} & \multirow[t]{2}{*}{0.115} & 0.000 \\
\hline & & & NULL & & & 4.599 \\
\hline & $\mathrm{NAR}_{\mathrm{a}}$ & Seed mass + maximum VWC & $\begin{array}{l}\text { MM } \\
\text { NULL }\end{array}$ &,++ & 0.234 & $\begin{array}{r}0.000 \\
10.362\end{array}$ \\
\hline & $\mathrm{LAR}_{\mathrm{a}}$ & Seed mass + R:FR & $\begin{array}{l}\text { EXP } \\
\text { NULL }\end{array}$ &,-- & 0.249 & $\begin{array}{r}0.000 \\
11.471\end{array}$ \\
\hline & \multirow{2}{*}{$\mathrm{LMF}_{\mathrm{a}}$} & GSF & MM & + & 0.273 & 0.000 \\
\hline & & $\mathrm{R}: \mathrm{FR}+$ maximun VWC & $\begin{array}{l}\text { LIN } \\
\text { NULL }\end{array}$ &,+- & 0.285 & $\begin{array}{r}1.361 \\
15.619\end{array}$ \\
\hline & Total leaf area & Seed mass + superficial compaction & $\begin{array}{l}\text { LIN } \\
\text { NULL }\end{array}$ &,+- & 0.356 & $\begin{array}{r}0.000 \\
20.124\end{array}$ \\
\hline & \multirow{2}{*}{ Number of leaves } & Seed mass + superficial compaction & EXP &,+- & 0.283 & 0.000 \\
\hline & & Seed mass $\times$ soil depth & $\begin{array}{l}\text { EXP } \\
\text { NULL }\end{array}$ &,++ & 0.251 & $\begin{array}{r}0.887 \\
11.663\end{array}$ \\
\hline & Stem height & Seed mass + superficial compaction + GSF & $\begin{array}{l}\text { LIN } \\
\text { NULL }\end{array}$ &,,+-- & 0.306 & $\begin{array}{r}0.000 \\
13.465\end{array}$ \\
\hline & SSL & Seed mass $+\mathrm{NT}+\mathrm{MAXIMUMVW} \mathrm{C}$ & $\begin{array}{l}\text { LIN } \\
\text { NULL }\end{array}$ &,,-+- & 0.353 & $\begin{array}{c}0.000 \\
17.43\end{array}$ \\
\hline Q.pyrenaica & Total aboveground biomass & Seed mass & EXP & + & 0.184 & 0.000 \\
\hline & RGRa & Seed mass + R:FR & LIN &,+- & 0.305 & 0.000 \\
\hline & $\mathrm{NAR}_{\mathrm{a}}$ & Seed mass + R:FR & $\begin{array}{l}\text { NULL } \\
\text { EXP } \\
\text { NULL }\end{array}$ &,+- & 0.379 & $\begin{array}{r}12.386 \\
0.000 \\
17.687\end{array}$ \\
\hline & $\mathrm{LAR}_{\mathrm{a}}$ & $\mathrm{pH}$ & $\begin{array}{l}\text { LIN } \\
\text { NULL }\end{array}$ & - & 0.096 & $\begin{array}{l}0.000 \\
2.473\end{array}$ \\
\hline & $\mathrm{LMF}_{\mathrm{a}}$ & $\mathrm{pH}+\mathrm{R}: \mathrm{FR}$ & $\begin{array}{l}\text { LIN } \\
\text { NULL }\end{array}$ &,-+ & 0.525 & $\begin{array}{r}0.000 \\
30.259\end{array}$ \\
\hline & Total leaf area & Seed mass $+\mathrm{pH}$ & $\begin{array}{l}\text { LIN } \\
\text { NULL }\end{array}$ &,+- & 0.251 & $\begin{array}{l}0.000 \\
8.92\end{array}$ \\
\hline & Number of leaves & & NULL & & & \\
\hline & Stem height & GSF & $\begin{array}{l}\text { EXP } \\
\text { NULL }\end{array}$ & - & 0.417 & $\begin{array}{r}0.000 \\
23.044\end{array}$ \\
\hline & SSL & GSF & $\begin{array}{l}\text { EXP } \\
\text { NULL }\end{array}$ & - & 0.244 & $\begin{array}{c}0.000 \\
10.83\end{array}$ \\
\hline Q. suber & Total aboveground biomass & Seed mass & $\mathrm{MM}$ & + & 0.150 & 0.000 \\
\hline & & & NULL & & & 6.873 \\
\hline & RGRa & R:FR & $\begin{array}{l}\text { LIN } \\
\text { NULL }\end{array}$ & - & 0.168 & $\begin{array}{l}0.000 \\
7.484\end{array}$ \\
\hline & $\mathrm{NAR}_{\mathrm{a}}$ & $\mathrm{R}: \mathrm{FR}$ & $\begin{array}{l}\text { LIN } \\
\text { NULL }\end{array}$ & - & 0.161 & $\begin{array}{l}0.000 \\
7.076\end{array}$ \\
\hline & $\mathrm{LAR}_{\mathrm{a}}$ & Seed mass $+\mathrm{R}: \mathrm{FR}+\mathrm{NH} 4$ & $\begin{array}{l}\text { LIN } \\
\text { NULL }\end{array}$ &,,--+ & 0.439 & $\begin{array}{r}0.000 \\
25.445\end{array}$ \\
\hline & $\mathrm{LMF}_{\mathrm{a}}$ & GSF & $\begin{array}{l}\text { LIN } \\
\text { NULL }\end{array}$ & + & 0.473 & $\begin{array}{r}0.000 \\
33.657\end{array}$ \\
\hline & Total leaf area & Seed mass & $\begin{array}{l}\text { MM } \\
\text { NULL }\end{array}$ & + & 0.112 & $\begin{array}{l}0.000 \\
4.389\end{array}$ \\
\hline & Number of leaves & GSF + superficial compaction & $\begin{array}{l}\text { EXP } \\
\text { NULL }\end{array}$ &,+- & 0.153 & $\begin{array}{r}0.000 \\
15.249\end{array}$ \\
\hline & $\begin{array}{l}\text { Stem height } \\
\text { SSL }\end{array}$ & Seed mass + R:FR & $\begin{array}{l}\text { EXP } \\
\text { NULL }\end{array}$ &,+- & 0.380 & $\begin{array}{r}0.000 \\
22.182\end{array}$ \\
\hline
\end{tabular}

pyrenaica than for the other two species (support intervals for the intercept $-a$ parameter - in the null models overlapped for these two species, Table 2 and Appendix S3). None of the measured factors were selected as predictors of total aboveground biomass and $\mathrm{RGR}_{\mathrm{a}}$ for the two deciduous species (Table 5). In contrast, $Q$. suber seedlings were highly affected by seed mass and light conditions (Table 5). Consequently, $Q$. suber outgrew its co-dominant oak species (Q. canariensis) at high values of seed 
Table 4. Summary of the models analysing the relations among growth parameters for the three oak species during the two growing seasons. The $R^{2}$ values and the best functional forms (LIN, Linear; EXP, Exponential; MM, Michaelis-Menten) are showed for all the possible combinations. The strength of empirical support (based on the absolute magnitude of the differences in $\mathrm{AIC}_{\mathrm{c}}$ with the null model) is indicated as follows: ${ }^{*} 2 \leq \Delta \mathrm{AIC} \leq 7{ }^{* *} 7 \leq \Delta \mathrm{AIC} \leq 14 ; * * * 14 \leq \Delta \mathrm{AIC}$. The type of relationship between growth parameters was always positive.

\begin{tabular}{|c|c|c|c|c|c|c|c|c|c|c|c|}
\hline \multirow[t]{2}{*}{ Species } & \multirow{2}{*}{$\begin{array}{l}\text { Growth } \\
\text { parameters }\end{array}$} & \multicolumn{5}{|c|}{ First growing season } & \multicolumn{5}{|c|}{ Second growing season } \\
\hline & & $\begin{array}{l}\text { Total } \\
\text { Ab. } \\
\text { Biomass }\end{array}$ & RGRa & $\mathrm{NAR}_{\mathrm{a}}$ & $\mathrm{LAR}_{\mathrm{a}}$ & LMRa & $\begin{array}{l}\text { Total } \\
\text { Ab. } \\
\text { Biomass }\end{array}$ & RGRa & $\mathrm{NAR}_{\mathrm{a}}$ & $\mathrm{LAR}_{\mathrm{a}}$ & LMRa \\
\hline \multirow[t]{4}{*}{ Q. canariensis } & $\begin{array}{l}\text { Total Ab. } \\
\text { Biomass }\end{array}$ & - & $\begin{array}{l}\text { 0.12* } \\
{[\text { LIN] }}\end{array}$ & $\begin{array}{l}0.15^{* * *} \\
{[\mathrm{LIN}]}\end{array}$ & $\begin{array}{l}0.25^{* *} \\
{[\mathrm{LIN}]}\end{array}$ & 0 & - & $\begin{array}{c}0.47^{* * *} \\
{[\mathrm{LIN}]}\end{array}$ & $\begin{array}{c}\mathbf{0 . 6 0} 0^{* * *} \\
{[\mathrm{LIN}]}\end{array}$ & 0 & 0.07 \\
\hline & RGRa & - & - & $\begin{array}{c}0.87^{* * *} \\
{[\mathrm{LIN}]}\end{array}$ & 0 & 0 & - & - & $\begin{array}{c}0.76^{* * *} \\
{[\mathrm{LIN}]}\end{array}$ & $\begin{array}{l}\mathbf{0 . 2 3}^{*} \\
{[\mathrm{LIN}]}\end{array}$ & $\begin{array}{l}\mathbf{0 . 3 8}^{* *} \\
{[\mathrm{LIN}]}\end{array}$ \\
\hline & $\mathrm{NAR}_{\mathrm{a}}$ & - & - & - & 0.06 & 0 & - & - & - & 0.02 & 0.1 \\
\hline & $\mathrm{LAR}_{\mathrm{a}}$ & - & - & - & - & $\begin{array}{l}\mathbf{0 . 1 2} \\
{[\mathrm{MM}]}\end{array}$ & - & - & - & - & $\begin{array}{c}0.48^{* * *} \\
{[\mathrm{MM}]}\end{array}$ \\
\hline \multirow[t]{4}{*}{$Q$. pyrenaica } & $\begin{array}{l}\text { Total Ab. } \\
\text { Biomass }\end{array}$ & - & $\begin{array}{c}\mathbf{0 . 1 1}^{*} \\
{[\mathrm{EXP} ; \mathrm{LIN}]}\end{array}$ & $\begin{array}{c}\mathbf{0 . 1 2}^{*} \\
{[\mathrm{EXP} ; \mathrm{LIN}]}\end{array}$ & 0 & 0.08 & - & $\begin{array}{c}0.60^{* *} \\
{[\mathrm{LIN}]}\end{array}$ & $\begin{array}{c}\mathbf{0 . 5 9} \\
{[\mathrm{LIN}]}\end{array}$ & 0.08 & 0.06 \\
\hline & RGRa & - & - & $\begin{array}{c}\mathbf{0 . 7 4} * * * \\
{[\mathrm{EXP}]}\end{array}$ & 0 & 0.07 & - & - & $\begin{array}{c}\mathbf{0 . 9 8}^{* * *} \\
{[\mathrm{LIN}]}\end{array}$ & 0 & 0.02 \\
\hline & $\mathrm{NAR}_{\mathrm{a}}$ & - & - & - & 0 & 0.08 & - & - & - & 0 & 0.02 \\
\hline & $\mathrm{LAR}_{\mathrm{a}}$ & - & - & - & - & $\begin{array}{c}\mathbf{0 . 4 2} \mathbf{2}^{* * *} \\
{[\mathrm{MM}]}\end{array}$ & - & - & - & - & $\begin{array}{c}0.94^{* * *} \\
{[\mathrm{MM}]}\end{array}$ \\
\hline \multirow[t]{4}{*}{ Q. suber } & $\begin{array}{l}\text { Total Ab. } \\
\text { Biomass }\end{array}$ & - & $\begin{array}{l}\mathbf{0 . 1 9}{ }^{* *} \\
{[\mathrm{LIN}]}\end{array}$ & $\begin{array}{l}0.26 * * \\
{[\mathrm{LIN}]}\end{array}$ & 0.02 & 0.01 & - & $\begin{array}{c}0.57^{* * *} \\
{[\mathrm{LIN}]}\end{array}$ & $\begin{array}{c}\mathbf{0 . 6 0}^{* * *} \\
{[\mathrm{LIN}]}\end{array}$ & 0.01 & 0.13 \\
\hline & RGRa & - & - & $\begin{array}{c}\mathbf{0 . 8 9}^{* * * *} \\
{[\mathrm{LIN}]}\end{array}$ & $\begin{array}{l}0.16^{* *} \\
{[\mathrm{LIN}]}\end{array}$ & 0 & - & - & $\begin{array}{c}0.99^{* * *} \\
{[\mathrm{LIN}]}\end{array}$ & 0.15 & $\begin{array}{c}\mathbf{0 . 5 3}^{* * *} \\
{[\mathrm{LIN}]}\end{array}$ \\
\hline & $\mathrm{NAR}_{\mathrm{a}}$ & - & - & - & 0.05 & 0.02 & - & - & - & 0.12 & $\begin{array}{l}\mathbf{0 . 3 3}^{* *} \\
{[\mathrm{LIN}]}\end{array}$ \\
\hline & $\mathrm{LAR}_{\mathrm{a}}$ & - & - & - & - & 0.06 & - & - & - & - & $\begin{array}{c}\mathbf{0 . 5 7 ^ { * * * }} \\
{[\mathrm{MM}]}\end{array}$ \\
\hline
\end{tabular}

mass and GSF, whereas $Q$. pyrenaica was exceeded by these two species across most seed ranges and light conditions (Fig. $4 a$ and b).

The mean annual $\mathrm{RGR}_{\mathrm{a}}$ was highest for $Q . \mathrm{ca}$ nariensis, followed by $Q$. pyrenaica and then $Q$. suber (Table 2); however, the support intervals for the intercept ( $a$ parameter) in the null models overlapped for the three species, indicating the lack of strong support for inter-specific differences in the mean $\mathrm{RGR}_{\mathrm{a}}$ (Appendix S3). In contrast to the first year, $Q$. suber seedlings had a higher $\mathrm{RGR}_{\mathrm{a}}$ than the other two species in the most open microsites (i.e. high values of GSF and R:FR), and the opposite was true for the most shaded microsites (i.e. low values of GSF and R:FR), where $\mathrm{RGR}_{\mathrm{a}}$ even reached negative values (Fig. 4c). This was probably a consequence of leaf shedding in those $Q$. suber seedlings growing in the most shaded microsites (data not shown).

Similar to the first growing season, total aboveground biomass was largely explained by the variation in $\mathrm{RGR}_{\mathrm{a}}$ (Table 4) for the three oak species. $\mathrm{RGR}_{\mathrm{a}}$ was again strongly correlated with the physiological component (Table 4 and Fig. 3). In this case, the morphological variables had greater influence on $\mathrm{RGR}_{\mathrm{a}}$ than in the first year, $\mathrm{LAR}_{\mathrm{a}}$ and $\mathrm{LMR}_{\mathrm{a}}$ appearing as marked predictors of $\mathrm{RGR}_{\mathrm{a}}$ for $Q$. canariensis and $Q$. suber (Table 4 and Fig. 3).

Regarding biomass allocation, light conditions (GSF and R:FR) were again the best predictors of $\mathrm{LMR}_{\mathrm{a}}$ for the three species (Table 5). In addition, there was evidence of a negative relationship with soil phosphorus in the case of $Q$. canariensis (Table 5).

After two growing seasons, $Q$. suber seedlings continued to be taller than the other two species (Table 2); however, the support intervals for the intercept ( $a$ parameter) in the null models overlapped for the three species (Appendix S3). Stem height was affected by the same predictor variables as during the first year (mainly seed mass and light conditions), although this time superficial soil compaction exerted a negative effect on $Q$. pyrenaica but not on Q. canariensis (Table 5).

Finally, the main factors explaining the rest of the morphological variables for second-year seedlings were seed mass, light conditions and soil compaction (especially in the case of $Q$. canariensis), which exerted a similar effect to that in the first year (Table 5). The relationships between growth para- 
Table 5. Summary of the models analysing the response of second-year seedling growth to seed mass and abiotic factors. Only the models with the best empirical support (lowest AIC) are shown. Models are noted and evaluated as in Table 3.

\begin{tabular}{|c|c|c|c|c|c|c|}
\hline Species & Growth variable & Predictors & $\mathrm{FF}$ & Relation & $R^{2}$ & $\Delta \mathrm{AIC}$ \\
\hline \multirow[t]{16}{*}{ Q. canariensis } & Total aboveground biomass & & NULL & & & \\
\hline & RGRa & & NULL & & & \\
\hline & $\mathrm{NAR}_{\mathrm{a}}$ & & NULL & & & \\
\hline & $\mathrm{LAR}_{\mathrm{a}}$ & & NULL & & & \\
\hline & $\mathrm{LMF}_{\mathrm{a}}$ & GSF & LIN & + & 0.129 & 0.000 \\
\hline & & $\mathrm{P}$ & LIN & - & 0.119 & 0.434 \\
\hline & & R:FR & LIN & + & 0.116 & 0.561 \\
\hline & & & NULL & & & 2.598 \\
\hline & Total leaf area & Superficial compaction & LIN & - & 0.156 & 0.000 \\
\hline & & & NULL & & & 3.725 \\
\hline & Number of leaves & Superficial compaction + GSF & EXP &,+- & 0.552 & 0.000 \\
\hline & & & NULL & & & 62.446 \\
\hline & Stem height & Seed mass + GSF & EXP &,+- & 0.468 & 0.000 \\
\hline & & & NULL & & & 17.798 \\
\hline & SSL & Max. Compaction + minimum VWC & EXP &,++ & 0.340 & 0.000 \\
\hline & & & NULL & & & 10.020 \\
\hline \multirow[t]{15}{*}{ Q.pyrenaica } & Total aboveground biomass & & NULL & & & \\
\hline & RGRa & & NULL & & & \\
\hline & $\mathrm{NAR}_{\mathrm{a}}$ & & NULL & & & \\
\hline & $\mathrm{LAR}_{\mathrm{a}}$ & $\mathrm{P}$ & EXP & - & 0.194 & 0.000 \\
\hline & & GSF & LIN & + & 0.173 & 0.767 \\
\hline & & NH4 & EXP & - & 0.166 & 1.019 \\
\hline & & R:FR & EXP & + & 0.153 & 1.442 \\
\hline & & & NULL & & & 3.769 \\
\hline & $\mathrm{LMF}_{\mathrm{a}}$ & GSF & MM & + & 0.398 & 0.000 \\
\hline & & & NULL & & & 12.211 \\
\hline & Total leaf area & & NULL & & & \\
\hline & Number of leaves & & NULL & & & \\
\hline & Stem height & $\mathrm{R}: \mathrm{FR}+$ superficial compaction & EXP &,-- & 0.740 & 0.000 \\
\hline & & & NULL & & & 33.824 \\
\hline & SSL & & NULL & & & \\
\hline \multirow[t]{17}{*}{ Q. suber } & Total aboveground biomass & Seed mass + GSF & LIN &,++ & 0.650 & 0.000 \\
\hline & & & NULL & & 0.000 & 26.357 \\
\hline & RGRa & GSF & LIN & + & 0.405 & 0.000 \\
\hline & & R:FR & LIN & + & 0.386 & 0.711 \\
\hline & & & NULL & & & 9.012 \\
\hline & $\mathrm{NAR}_{\mathrm{a}}$ & & NULL & & & \\
\hline & $\mathrm{LAR}_{\mathrm{a}}$ & & NULL & & & \\
\hline & $\mathrm{LMF}_{\mathrm{a}}$ & GSF & MM & + & 0.497 & 0.000 \\
\hline & & & NULL & & & 18.154 \\
\hline & Total leaf area & Seed mass + GSF & LIN &,++ & 0.632 & 0.000 \\
\hline & & & NULL & & & 24.826 \\
\hline & Number of leaves & GSF & EXP & + & 0.702 & 0.000 \\
\hline & & & NULL & & & 154.578 \\
\hline & Stem height & Seed mass + R:FR & EXP &,+- & 0.630 & 0.000 \\
\hline & & & NULL & & & 24.679 \\
\hline & SSL & Seed mass + R:FR & LIN &,-- & 0.544 & 0.000 \\
\hline & & & NULL & & & 18.390 \\
\hline
\end{tabular}

meters and the main factors considered in this study (seed mass, light conditions and soil variables) are summarised in Fig. 5 for the two growing seasons.

\section{Discussion}

\section{Factors affecting seedling growth and morphology}

Seedling growth and morphology may be affected by a large number of resources and environmental conditions; however, results from our modelling approach showed that the integrative variables of seedling growth $-\mathrm{RGR}_{\mathrm{a}}$ and total aboveground biomass - were affected by two main factors: light conditions and seed mass. Interestingly, the relative contribution of these two factors depended strongly on seedling age. Light affected seedling performance of 2-year-old seedlings, whereas during early growth, younger seedlings were more dependent on seed mass. Several soil factors, such as compaction, $\mathrm{pH}$, water content and nutrient content (phosphorus and nitrogen), were also good predictors of certain morphological variables, but none of them had an important effect on the integrative variables of seedling growth (Fig. 5). 

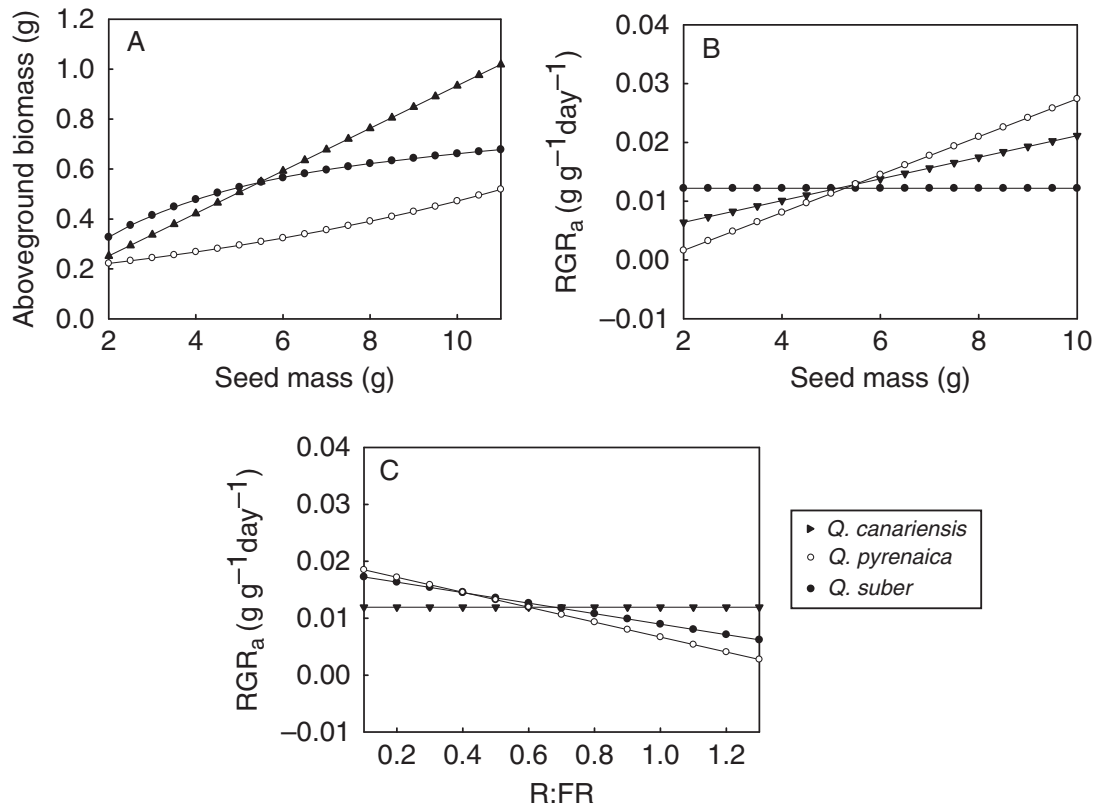

Fig. 2. Predicted variation in seedling aboveground biomass and relative growth rate $\left(R_{G} R_{a}\right)$ as a function of the best predictors (Table 3 ) for the first growing season. (a) Seedling aboveground biomass along the seed mass range; (b) RGR $\mathrm{R}_{\mathrm{a}}$ as a function of seed mass for intermediate values of red:far red ratio (R:FR $=0.65)$; (c) $R G R_{a}$ along the gradient of $R: F R$ for an average seed mass of $5 \mathrm{~g}$. Straight lines denote no effect of the considered factor on first-year $\mathrm{RGR}_{\mathrm{a}}$, but are included for comparative purposes.

\section{Light conditions}

Light was the best environmental predictor of many variables related to seedling morphology for the three studied oak species, especially during the second year. However, its influence on seedling growth varied according to the species and the growing season. Seedling growth and morphology depended not only on light availability (GSF), but also on its spectral quality (R:FR), which highlights the importance of this factor as a mediator of seedling performance in tree species (Lee et al. 1997; Ammer 2003; Tegelberg et al. 2004). In shade conditions (i.e. in microsites with lower values of R:FR and GSF), seedlings of the three studied species were taller, sometimes at the expense of increased thinness of their stems (higher SSL). This pattern is typical of plants growing in microsites where the $\mathrm{R}: \mathrm{FR}$ is reduced, that increase stem height as a mechanism of shade avoidance (Ammer 2003; Tegelberg et al. 2004). The enhanced stem height with shade could be one of the main contributors to the negative linear relationship found between $\mathrm{RGR}_{\mathrm{a}}$ and R:FR for $Q$. suber and $Q$. pyrenaica during the first growing season (Fig. 2c). The nonsensitivity of $Q$. canariensis to R:FR, which can be considered a typical response of shade-tolerant species (Kwesiga \& Grace 1986; Kitajima 1994), reveals its higher degree of tolerance to low light environ- ments in comparison with the other two studied species.

During the second year, the three oak species retained the same response of higher stem elongation in shaded microsites, but seedling growth was independent of light conditions for the two deciduous species. In contrast, in the evergreen $Q$. suber seedlings, biomass increased with light (Fig. 4b), and RGR decreased to negative values in deep shade microsites (Fig. 4c). The net carbon balance for this species probably became negative under limiting light conditions, when seed reserves were depleted and seedlings were more dependent on external resources. This hypothesis is supported by the marked leaf shedding (net carbon loss) in many $Q$. suber seedlings in these low light microsites during the second year. These results are in accordance with Cardillo \& Bernal (2006), who classified $Q$. suber as a species of intermediate tolerance to shade. The observed pattern of enhanced seedling growth with increasing light is consistent with previous studies (Pacala et al. 1994; Sack \& Grubb 2002; Quero et al. 2006; Sánchez-Gómez et al. 2006), but contrasts with others that have documented maximum values of RGR in intermediate (Veenendaal et al. 1996; Poorter 1999; Puerta-Piñero et al. 2007; Quero et al. 2008) or even low light conditions (Holmgren 2000). The absence of a negative response to light scarcity 

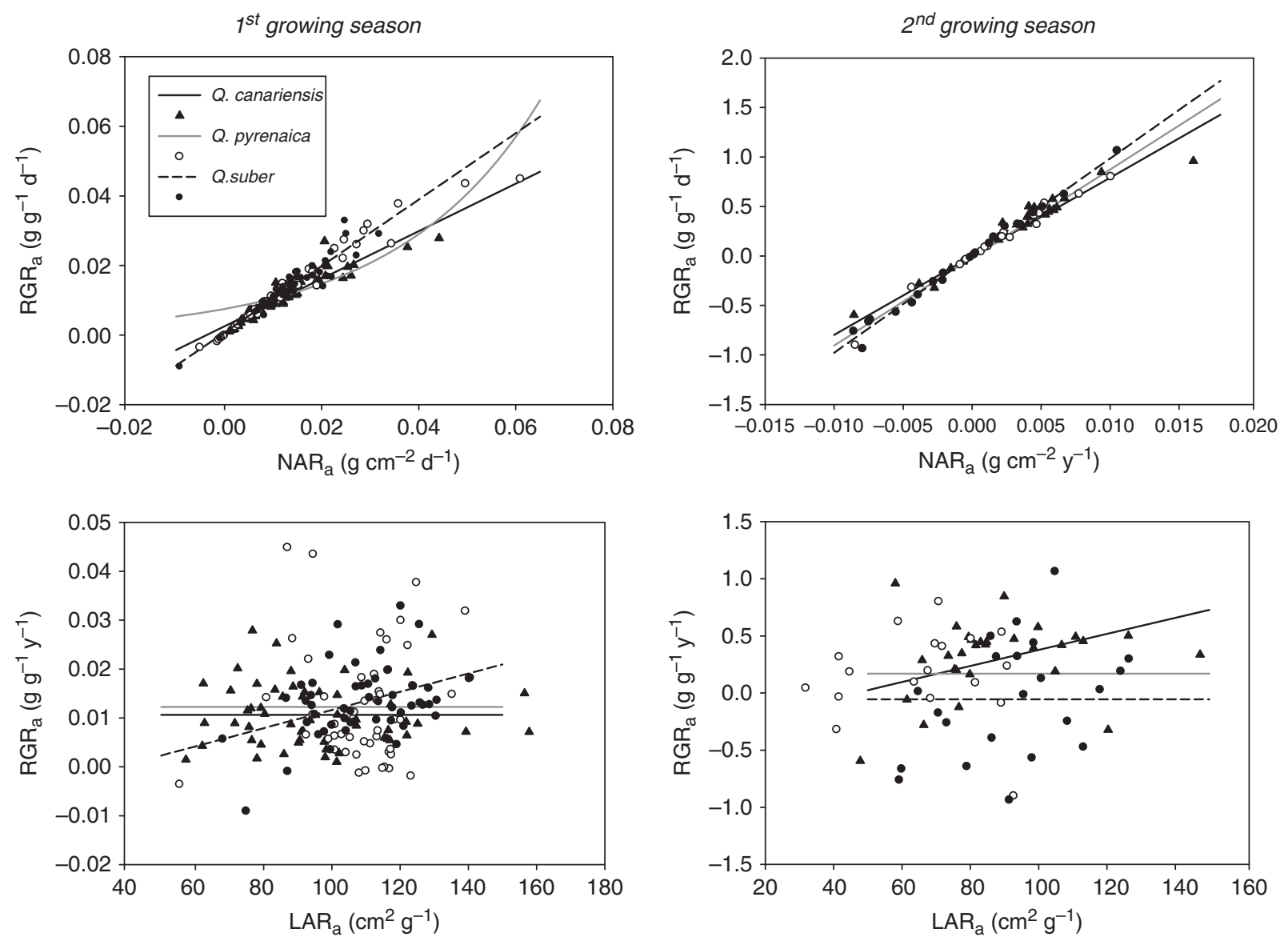

Fig. 3. Relationships between the relative growth rate $\left(R_{G} R_{a}\right)$ and its two main components $\left(N A R_{a}\right.$ and $\left.L A R_{a}\right)$ for the two growing seasons, following the models in Table 4.

for the two deciduous species could be a consequence, at least partially, of their high tolerance to shade during early life stages (Gómez-Aparicio et al. 2006; Quero et al. 2006). In addition, the proportion of deep shade microsites ( $<10 \%$ full sunlight) was relatively low at the study site, which is typical of Mediterranean forests (Gómez et al. 2004; Quilchano et al. 2008). Therefore, the type of relationship between seedling growth and light is strongly variable, and appears to be affected by several factors, including the study system, the target species and the explored light gradient.

The three studied species also showed a high capacity of response to light conditions across the modification of certain structural plant and leaf traits. On one hand, oak seedlings usually had higher values of $\mathrm{LAR}_{\mathrm{a}}$ in low light environments, probably for maximising the light interception (Poorter 1999; Castro-Díez et al. 2005; Cardillo \& Bernal 2006). On the other hand, in the most open microsites, seedlings developed a higher number of leaves, usually of lower SLA. As a result of these opposing tendencies, the total leaf area remained constant over the range of observed light values. A similar total leaf surface of higher biomass in open microsites, together with a lower investment in stem height, were probably the main causes explaining the positive relationship between $\mathrm{LMR}_{\mathrm{a}}$ and light that was detected for the three species during the two growing seasons.

\section{Soil factors}

Surprisingly, none of the soil factors considered in this study (nutrient and water availability, texture or compaction) exerted an important effect on the integrative variables of oak seedling growth. Nevertheless, several morphological traits of the seedling were affected by soil factors.

Superficial compaction exponentially reduced the number of leaves for two of the studied species, and linearly the total leaf area in the case of $Q$. canariensis. In addition, stem height was negatively correlated with soil compaction for the two deciduous species. In general, higher soil compaction 

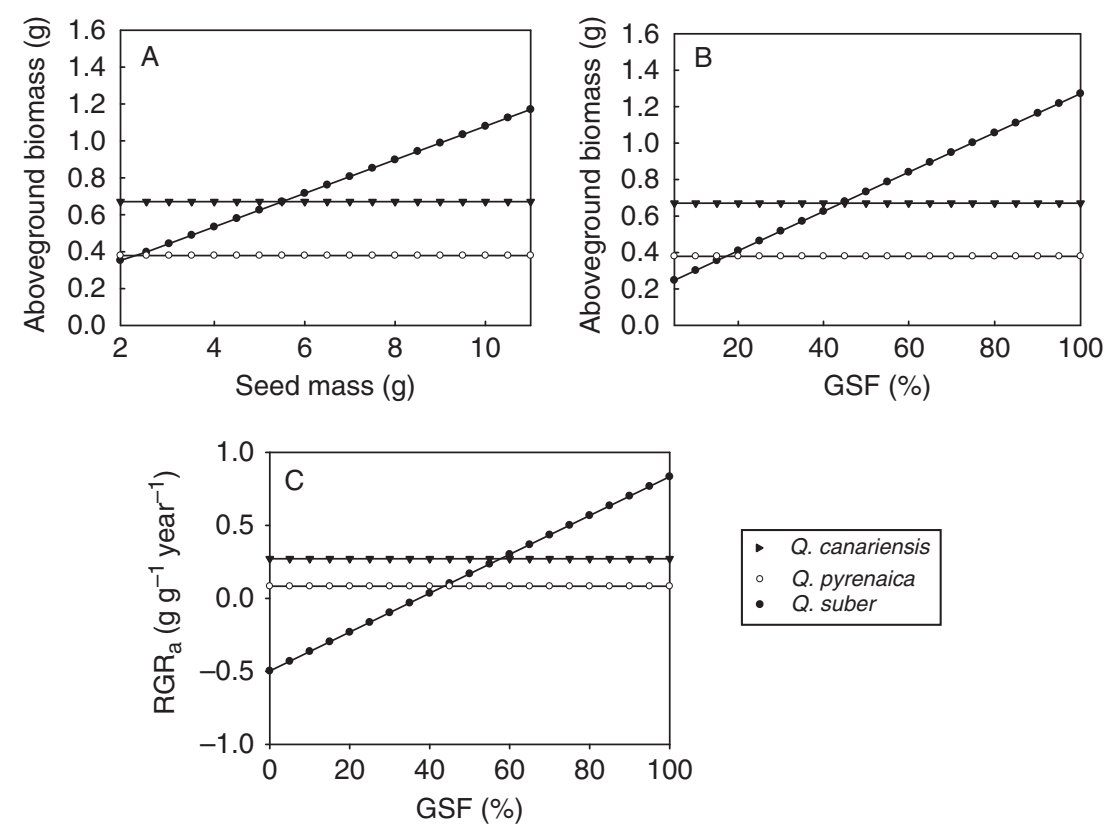

Fig. 4. Predicted variation in seedling aboveground biomass and relative growth rate $\left(R_{G} R_{a}\right)$ as a function of the best predictors (Table 4) for the second growing season. (a) Seedling aboveground biomass along the seed mass range for intermediate values of global site factor $(\mathrm{GSF}=40 \%$ ); (b) seedling aboveground biomass as a function of GSF for an average seed mass of $5 \mathrm{~g}$; (c) $\mathrm{RGR}_{\mathrm{a}}$ along the gradient of GSF. Straight lines denote no effect of the considered factor on second-year $\mathrm{RGR}_{\mathrm{a}}$, but are included for comparative purposes.

means stronger resistance of the substrate to penetration by the fine radicle of the growing seedling (Kozlowski 1999; Basset et al. 2005). A compacted soil could limit root growth of the seedling (Verdú \& García-Fayos 1996), reduce its capacity for nutrient assimilation (Lloret et al. 1999) and, therefore, negatively affect some of its aboveground growth variables (e.g. Basset et al. 2005; Alameda \& Villar 2009). The effect of soil compaction was more marked for $Q$. canariensis than for the other two species, probably as a consequence of the smaller root system developed by this species during the first months of its life (demonstrated in a parallel study under laboratory conditions; Pérez-Ramos \& Marañón 2009).

Soil moisture also affected other morphological and physiological variables of the seedling in the case of $Q$. canariensis. However, excess water during the rainy season - and not water shortage in summer - was selected as a negative and better predictor of certain variables related to seedling growth. This could be due to the fact that high soil water levels lengthened time to emergence of seedlings (Urbieta et al. 2008a), which in turn reduced the time available for growth before the end of the favourable season. The apparent lack of response to summer water deficit was probably a direct consequence of the uniformly low values of soil VWC recorded during the dry season along the whole explored light gradient (Table 1).

Models that incorporated several soil nutrients, such as nitrogen or phosphorus, had higher empirical support for some morphological variables than did models based only on seed mass or light. For example, oak seedlings growing in soils with a higher nitrogen content showed higher values of SSL (for $Q$. canariensis) or $\mathrm{LAR}_{\mathrm{a}}$ (in the case of $Q$. suber) during the first growing season. The importance of soil nutrients on tree seedling growth has been amply reported in other studies that document positive effects of nursery fertilisation (e.g. Van den Driessche 1982; Villar-Salvador et al. 2004). However, the three studied oak species exhibited, under field conditions, a very limited response to nutrient availability in comparison with seed mass or light. In general, this low leaf-level responsiveness to nutrients in Mediterranean woody plants is considered part of a conservative resource-use strategy (Valladares et al. 2000), including a reduced demand for resources (Sack et al. 2003). In addition, the counteracting gradients of light and soil nutrients (Fig. 1) - mainly derived from the relationship between canopy density and litter accumulation (García et al. 2006) - may counterbalance oak seedling performance in microsites with high light availability but nutrient-poor soils, in comparison with shaded mi- 
crosites that are richer in nutrients but limited in light.

\section{Seed mass}

The amount of reserves contained in the seed was the main factor affecting seedling growth for the three oak species during the first year of life. During the second year, seedling aboveground biomass was still highly dependent on the initial seed mass in the case of $Q$. suber, but this factor did not affect its RGR, or exert any effect at all in the other two species. The differential importance of seed size with oak seedling age confirms the strong dependence on seed reserves during early growth (Long \& Jones 1996; Quero et al. 2007, 2008). Other studies have also shown that the strength of correlation between growth variables and seed mass declines over time, and tends to disappear after several years (Castro 1999; Poorter \& Rose 2005; Quero et al. 2007).

Seed mass also affected other morphological variables. In general, the larger-seeded seedlings had a larger total leaf area, a higher number of leaves and a lower $\mathrm{LAR}_{\mathrm{a}}$. Regarding variables related to the stem, the bigger the seed the taller the resulting seedling, and, sometimes, the lower its SSL. The negative relationships with $\mathrm{LAR}_{\mathrm{a}}$ and SSL could be interpreted as mechanisms for maximising light interception, and thus seedling growth; the smallerseeded seedlings would achieve greater leaf photosynthetic surface and greater stem height at the expense of having thinner leaves and stems.

\section{Inter-specific differences in seedling growth along resource gradients}

The specialisation along resource availability gradients during seedling establishment, as part of the regeneration niche, is one of the frequently hypothesised mechanisms for species coexistence in plant communities (Grubb 1977; Silvertown 2004). Specifically, how resources influence seedling growth could affect forest dynamics and species distribution across resource gradients (Kobe 2006). The results of this study provide some evidence of regeneration niche partitioning between oak species along the light gradient. However, these inter-specific differences were variable for the first 2 years of seedling life. Although $Q$. canariensis had a higher RGR than the other two species in the most open microsites (i.e. high values of R:FR and GSF) during the first growing season (Fig. 2c), the following year $Q$. suber outgrew the two deciduous species in high light environments (Fig. $4 \mathrm{~b}$ and c). When light availability was scarce, many $Q$. suber seedlings lost a large amount of their leaves, reduced their growth rates (even reaching negatives values of $\mathrm{RGR}_{\mathrm{a}}$, probably as a consequence of a reduced carbon gain) and were thus exceeded by the other two species.

The differential species responses in second-year seedling growth along the light gradient are consistent with the observed seedling survival pattern, where the two deciduous species also exceeded the evergreen $Q$. suber in low light environments (Gómez-Aparicio et al. 2008). These results support the low light survival versus high light growth trade-off previously reported in other forest systems (Kobe et al. 1995; Pacala et al. 1996; Sánchez-Gómez et al. 2006). This pattern of seedling performance can be related to species habitat and distribution patterns in the study area, and supports the initial hypothesis proposing a higher shade tolerance for $Q$. canariensis seedlings in comparison with the co-dominant $Q$. suber. On the other hand, $Q$ pyrenaica was outperformed by the two dominant species along almost the whole light gradient. At the study site, this species appears as an accompanying species, frequently restricted to scarce populations at higher altitudes.

Seed mass also played a crucial role in interspecific differences, affecting the competitive hierarchies between oak species (Figs. $2 \mathrm{~b}$ and $4 \mathrm{a}$ ). Interspecific differences in seedling growth, arising from seed size variability and microsite heterogeneity, could be of paramount importance in oak species niche segregation, driving stand dynamics and composition along environmental gradients.

\section{Concluding remarks}

This study represents an example of an innovative combination of field experiments and statistical modelling, used here to identify the main factors affecting seedling growth and morphology in three oak species coexisting in a Mediterranean forest, and how species-specific responses vary along wide gradients of resources and environmental factors. Seedling growth $-\mathrm{RGR}_{\mathrm{a}}$ and total aboveground biomass - was affected by two main factors: light conditions and seed mass. The relative contribution of each factor depended highly on seedling age, supporting previous studies defining ontogenetic changes between seedlings and saplings (Cavender-Bares \& Bazzaz 2000) or among juveniles of different ages (Espelta et al. 1995).

For the two growing seasons, $\mathrm{NAR}_{\mathrm{a}}$ was the biggest factor contributing to RGR variation in the 

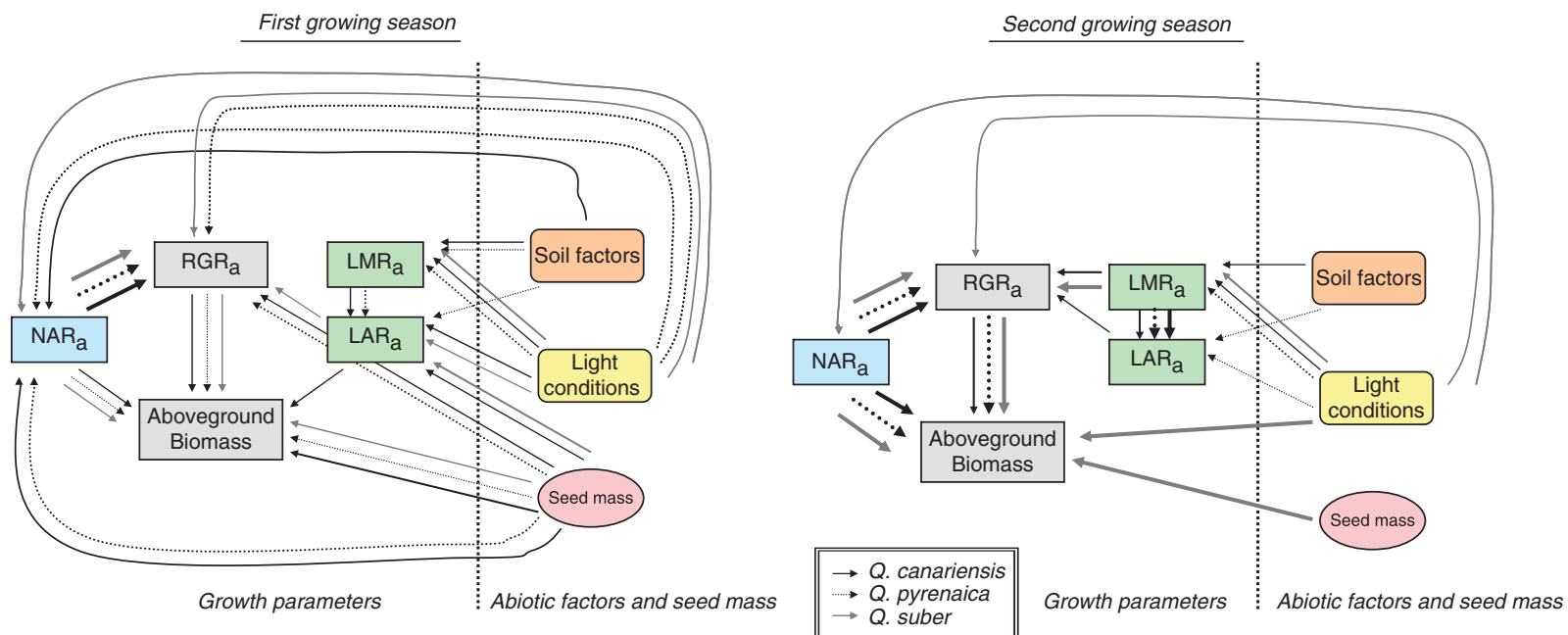

Fig. 5. Summary diagram on relationships among growth parameters and the main factors (seed mass, light conditions and soil variables) affecting them during the two growing seasons. The thickness of the arrows indicates the strength of the empirical support for the relationships between pairs of variables (see Tables 3-5).

three oak species (Figs. 3 and 5). These results are consistent with previous studies (Popma \& Bongers 1988; Poorter 2001), but contrast with others identifying the morphological component (LAR) as the primary factor explaining the high variability in RGR (e.g. Reich et al. 1992; Huante et al. 1995; Cornelissen et al. 1998; Antúnez et al. 2001).

The results of this study provide some evidence of regeneration niche partitioning between oak species along light gradients. Differences between leaf longevity functional groups depended strongly on the light environment explored; deciduous species outgrowing the evergreen species only at low light microsites. The information provided by our modelling approach is another necessary step towards the development of a mechanistic model that integrates species-specific responses for all recruitment stages (seed production and predation, seed germination and seedling emergence, survival and growth) in order to analyse general patterns of regeneration niche partitioning and species coexistence, and thus predict forest dynamics.

Acknowledgements. We thank the Consejería de Medio Ambiente (Andalusian Government) and Felipe Oliveros, then Director of Los Alcornocales Natural Park, for the facilities and support to carry out our fieldwork. We also thank Fernando Valladares for giving advice on light and R:FR measurements, J. L. Quero for unpublished data on $Q$. pyrenaica, and Semillas Silvestres (http://www.semillassilvestres.com) for providing seeds of $Q$. pyrenaica. We are tremendously grateful to Maite Domínguez, Itziar Rodriguez, Lola Vega, Eduardo Gutiérrez, Ana Polo and
Rocío Sánchez for invaluable field and lab assistance. This study was supported by a FPU-MEC grant to IMPR, a Juan de la Cierva contract to LGA and by the Spanish MEC projects Heteromed (REN2002-4041-C02-02), Dinamed (CGL2005-5830-C03-01/02) and Interbos (CGL2008-4503C03-01/02). This research is part of the Globimed (http:// www.globimed.net) network in forest ecology.

\section{References}

Alameda, D. \& Villar, R. 2009. Moderate soil compaction: implications on growth and architecture of 17 woody plants seedlings. Soil \& Tillage Research 103: 325-331.

Ammer, C. 2003. Growth and biomass partitioning of Fagus sylvatica L. and Quercus robur L. seedlings in response to shading and small changes in the R/FRratio of radiation. Annals of Forest Science 60: 163-171.

Anderson, M.C. 1964. Studies of the woodland light climate I. The photographic computation of light condition. Journal of Ecology 52: 27-41.

Antúnez, I., Retamosa, E.C. \& Villar, R. 2001. Relative growth rate in phylogenetically related deciduous and evergreen woody species. Oecologia 128: 172-180.

Aphalo, P.J. \& Lehto, T. 2001. Effect of lateral far-red light supplementation on the growth and morphology of birch seedlings and its interaction with mineral nutrition. Trees 15: 297-303.

Basset, I.E., Simcock, R.C. \& Mitchell, N.D. 2005. Consequences of soil compaction for seedling establishment: implications for natural regeneration and restoration. Austral Ecology 30: 827-833.

Blondel, J. \& Aronson, J. 1999. Biology and wildlife of the Mediteranean region. Oxford University Press, Oxford, UK. 
Burnham, K.P. \& Anderson, D.R. 2002. Model selection and multimodel inference: a practical informationtheoretic approach. 2nd ed. Springer, Berlin, DE.

Cardillo, E. \& Bernal, C.J. 2006. Morphological response and growth of cork oak (Quercus suber L.) seedlings at different shade levels. Forest Ecology and Management 222: 296-301.

Castro, J. 1999. Seed mass versus seedling performance in Scots pine: a maternally dependent trait. New Phytologist 144: 153-161.

Castro-Díez, P., Navarro, J., Pintado, A., Sancho, L.G. \& Maestro, M. 2005. Interactive effects of shade and irrigation on the performance of seedlings of three Mediterranean Quercus species. Tree Physiology 26: 389-400.

Cavender-Bares, J. \& Bazzaz, F.A. 2000. Changes in drought response strategies with ontogeny in Quercus rubra: implications for scaling from seedlings to mature trees. Oecologia 124: 8-18.

Cornelissen, J.H.C., Castro-Díez, P. \& Carnelli, A.C. 1998. Variation in relative growth rate among woody species: scaling up. In: Lambert, H., Poorter, H. \& Van Vuuren, M. (eds.) Inherent variation in plant growth. Physiological mechanisms and ecological consequences. Backhuys Publishers.

Di Castri, F., Goodall, D.W. \& Specht, R.L. 1981. Mediterranean-type shrublands. Elsevier Scientific Publishing Company.

Edwards, A.W.F. 1992. Likelihood - expanded edition. Johns Hopkins University Press, Baltimore, MD, US.

Espelta, J.M., Riba, M. \& Retana, J. 1995. Patterns of seedling recruitment in West-Mediterranean Quercus ilex forests influenced by canopy development. Journal of Vegetation Science 6: 465-472.

Espelta, J.M., Cortés, P., Mangiron, M. \& Retana, J. 2005. Differences in biomass partitioning, leaf nitrogen content, and water use efficiency (delta C-13) result in similar performance of seedlings of two Mediterranean oaks with contrasting leaf habit. Ecoscience 12: 447-454.

García, L.V., Maltez-Mouro, S., Pérez-Ramos, I.M., Freitas, H. \& Marañón, T. 2006. Counteracting gradients of light and soil nutrients in the understorey of Mediterranean oak forests. Web Ecology 6: 67-74.

Gilbert, I.R., Seavers, G.P., Jarvis, P.G. \& Smith, H. 1995. Photomorphogenesis and canopy dynamics. Phytochrome-mediated proximity perception accounts for the growth dynamics of canopies of Populus trichocarpa $\times$ deltoides 'Beaupré'. Plant, Cell and Environment 18: 475-497.

Gómez, J.M. 2004. Importance of burial and microhabitat on Quercus ilex early recruitment: non-additive effects on multiple demographic processes. Plant Ecology 172: 287-297.

Gómez, J.M., Valladares, F. \& Puerta-Piñero, C. 2004. Differences between structural and functional environmental heterogeneity caused by seed dispersal. Functional Ecology 18: 787-792.
Gómez, J.M., Puerta-Piñero, C. \& Schupp, E.W. 2008. Effectiveness of rodents as local seed dispersers of Holm Oaks. Oecologia 155: 529-537.

Gómez-Aparicio, L., Valladares, F. \& Zamora, R. 2006. Differential light responses of Mediterranean tree saplings: linking ecophysiology with regeneration niche in four co-occurring species. Tree Physiology 26: 947-958.

Gómez-Aparicio, L., Pérez-Ramos, I.M., Mendoza, I., Matías, L., Quero, J.L., Castro, J., Zamora, R. \& Marañón, T. 2008. Oak seedling survival and growth along resource gradients in Mediterranean forests: implications for regeneration in current and future environmental scenarios. Oikos 117: 1683-1699.

Gribko, L.S. \& Jones, W.E. 1995. Test of float method of assessing northern red oak acorn condition. Tree Planter's Notes 46: 143-147.

Grubb, P.J. 1977. The maintenance of species richness in plant communities: the importance of the regeneration niche. Biological Review 52: 107-145.

Grubb, P.J., Lee, W.G., Kollmann, J. \& Wilson, J.B. 1996. Interaction of irradiance and soil nutrient supply on growth of seedlings of ten European tall-shrub species and Fagus sylvatica. Journal of Ecology 84: 827-840.

Harper, J.L. 1977. Population biology of plants. Academic Press, San Diego, CA, US.

Holmgren, M. 2000. Combined effects of shade and drought on tulip poplar seedlings: trade-off in tolerance or facilitation? Oikos 90: 67-78.

Huante, P., Rincon, E. \& Acosta, I. 1995. Nutrient availability and growth rate of 34 woody species from a tropical deciduous forest in Mexico. Functional Ecology 9: 849-858.

Hunt, R. 1978. Plant growth analysis. Edward Arnold.

Ibañez, I. \& Schupp, E.W. 2001. Positive and negative interactions between environmental conditions affecting Cercocarpus ledifolius seedling survival. Oecologia 129: 543-550.

Kitajima, K. 1994. Relative importance of photosynthetic traits and allocation patterns as correlates of seedling shade tolerance of 13 tropical trees. Oecologia 98: 419-428.

Kobe, R.K. 1999. Light gradient partitioning among tropical tree species through differential seedling mortality and growth. Ecology 80: 187-201.

Kobe, R.K. 2006. Sapling growth as a function of light and landscape-level variation in soil water and foliar nitrogen in northern Michigan. Oecologia 147: 119-133.

Kobe, R.K., Pacala, S.W., Silander, J.A. \& Canham, C.D. 1995. Juvenile tree survivorship as a component of shade tolerance. Ecological Applications 5: 517-532.

Kollmann, J. \& Schill, H.P. 1996. Spatial patterns of dispersal, seed predation and germination during colonization of abandoned grassland by Quercus petraea and Corylus avellana. Vegetatio 125: 193-205.

Kozlowski, T.T. 1999. Soil compaction and growth of woody plants. Scandinavian Journal of Forest Research 14: 596-619. 
Kwesiga, F. \& Grace, J. 1986. The role of the red far-red ratio in the response of tropical tree seedlings to shade. Annals of Botany 57: 283-290.

Lee, D.W., Oberbauer, S.F., Krishnapilay, B., Mansor, M., Mohamad, H. \& Yap, S.K. 1997. Effects of irradiance and spectral quality on seedling development of two Southeast Asian Hopea species. Oecologia 110: 1-9.

Lloret, F., Casanovas, C. \& Peñuelas, J. 1999. Seedling survival of Mediterranean shrubland species in relation to root shoot ratio, seed size and water and nitrogen use. Functional Ecology 13: 210-216.

Long, T.J. \& Jones, R.H. 1996. Seedling growth strategies and seed size effects in fourteen oak species native to different soil moisture habitats. Trees 11: 1-8.

Pacala, S.W., Canham, C.D., Silander, J.A. \& Kobe, R.K. 1994. Sapling growth as a function of resources in a north temperate forest. Canadian Journal of Forest Research 24: 2172-2183.

Pacala, S.W., Canham, C.D., Saponara, J., Silander, J.A., Kobe, R.K. \& Ribbens, E. 1996. Forest models defined by field measurements: II Estimation, error analysis and dynamics. Ecological Monographs 66: 1-43.

Pérez-Ramos, I.M. 2007 Factores que condicionan la regeneración natural de especies leñosas en un bosque mediterráneo del sur de la Península Ibérica. $\mathrm{PhD}$ Thesis, University of Seville, ES.

Pérez-Ramos, I.M. \& Marañón, T. 2009. Effects of waterlogging on seed germination of three Mediterranean oak species: ecological implications. Acta Oecologica 35: 422-428.

Pérez-Ramos, I.M., Marañón, T., Lobo, J.M. \& Verdú, J.R. 2007. Acorn removal and dispersal by the dung beetle Thorectes lusitanicus: ecological implications. Ecological Entomology 32: 349-356.

Pérez-Ramos, I.M., Urbieta, T.I., Marañón, T., Zavala, M.A. \& Kobe, R.K. 2008a. Seed removal in two coexisting oak species: ecological consequences of seed size, plant cover and seed-drop timing. Oikos 117: 1386-1396.

Pérez-Ramos, I.M., Zavala, M.A., Marañón, T., DíazVilla, M.D. \& Valladares, F. 2008b. Dynamics of understorey diversity following shrub-clearing of cork oak forests: a five-year study. Forest Ecology and Management 255: 3242-3253.

Poorter, L. 1999. Growth responses of 15 rain forest tree species to a light gradient: the relative importance of morphological and physiological traits. Functional Ecology 13: 396-410.

Poorter, L. 2001. Light-dependent changes in biomass allocation and their importance for growth of rain forest tree species. Functional Ecology 15: 113-123.

Poorter, L. \& Rose, S.A. 2005. Light-dependent changes in the relationship between seed mass and seedling traits: a meta-analysis for rain forest tree species. Oecologia 142: 378-387.

Popma, J. \& Bongers, F. 1988. The effect of canopy gaps on growth and morphology of seedlings of rain forest species. Oecologia 75: 625-632.
Puerta-Piñero, C., Gómez, J.M. \& Valladares, F. 2007. Irradiance and oak seedling survival and growth in a heterogeneous environment. Forest Ecology and Management 242: 462-469.

Quero, J.L., Villar, R., Marañón, T. \& Zamora, R. 2006. Interactions of drought and shade effects on seedlings of four Quercus species: physiological and structural leaf responses. New Phytologist 170: 819 834.

Quero, J.L., Villar, R., Marañón, T., Zamora, R. \& Poorter, L. 2007. Seed-mass effects in four Mediterranean Quercus species (Fagaceae) growing in contrasting light environments. American Journal of Botany 94: 1795-1803.

Quero, J.L., Villar, R., Marañón, T., Zamora, R., Vega, D. \& Sack, L. 2008. Relating leaf photosynthetic rate to whole plant growth: drought and shade effects on seedlings of four Quercus species. Functional Ecology 35: 725-737.

Quilchano, C., Marañón, T., Pérez-Ramos, I.M., Noejovich, L., Valladares, F. \& Zavala, M.A. 2008. Patterns and ecological consequences of abiotic heterogeneity in managed cork oak forests of Southern Spain. Ecological Research 23: 127-139.

Reich, P.B., Walters, M.B. \& Ellsworth, D.S. 1992. Leaf life-span in relation to leaf, plant, and stand characteristics among diverse ecosystems. Ecological Monographs 62: 365-392.

Ruíz-Robleto, J. \& Villar, R. 2005. Relative growth rate and biomass allocation in ten woody species with different leaf longevity using phylogenetic independent contrasts (PICs). Plant Biology 7: 484-494.

Sack, L. \& Grubb, P.J. 2002. The combined impacts of deep shade and drought on the growth and biomass allocation of shade-tolerant woody seedlings. Oecologia 131: 175-185.

Sack, L., Grubb, P.J. \& Marañón, T. 2003. The functional morphology of juvenile plants tolerant of strong summer drought in shaded forest understories in southern Spain. Plant Ecology 168: 139-163.

Sánchez-Gómez, D., Valladares, F. \& Zavala, M.A. 2006. Performance of seedlings of Mediterranean woody species under experimental gradients of irradiance and water availability: trade-offs and evidence for niche differentiation. New Phytologist 170: 795 806.

Shipley, B. 2002. Trade-offs between net assimilation rate and specific leaf area in determining relative growth rate: Relationship with daily irradiance. Functional Ecology 16: 682-689.

Silvertown, J. 2004. Plant coexistence and the niche. Trends in Ecology and Evolution 19: 605-611.

Silvertown, J. \& Charlesworth, D. 2001. Introduction to plant population biology. Blackwell Science.

Tegelberg, R., Julkunen-Titto, R. \& Aphalo, P.J. 2004. Red far-red light ratio and UV-B radiation: their effects on leaf phenolics and growth of silver birch seedlings. Plant, Cell and Environment 27: 1005-1013. 
Turnbull, L.A., Paul-Victor, C., Schmid, B. \& Purves, D.W. 2008. Growth rates, seed size, and physiology: Do small-seeded species really grow faster? Ecology 89: $1352-1363$.

Urbieta, I.R., Pérez-Ramos, I.M., Zavala, M.A., Marañón, T. \& Kobe, R.K. 2008a. Soil water heterogeneity and emergence time control seedling establishment in three co-occurring oak species. Canadian Journal of Forest Research 38: 2382-2393.

Urbieta, T.I., Zavala, M.A. \& Marañón, T. 2008b. Human and non-human determinants of forest composition in southern Spain: evidence of shifts toward cork oak dominance as a result of management over the past century. Journal of Biogeography 35: 1688-1700.

Valladares, F. \& Sánchez-Gómez, D. 2006. Ecophysiological traits associated with drought in Mediterranean tree seedlings: individual responses versus interspecific trends in eleven species. Plant Biology 8: 688-697.

Valladares, F., Martinez-Ferri, E., Balaguer, L., PérezCorona, E. \& Manrique, E. 2000. Low leaf-level response to light and nutrients in Mediterranean evergreen oaks: a conservative resource-use strategy? New Phytologist 148: 79-91.

Van den Driessche, R. 1982. Relationship between spacing and nitrogen fertilization of seedlings in the nursery, seedling size, and outplanting performance. Canadian Journal of Forest Research 12: 865-875.

Veenendaal, E.M., Swaine, M.D., Lecha, R.T., Falsh, M.F., Abebrese, I.K. \& Owusu-Afriyie, K. 1996. Responses of West African forest tree seedlings to irradiance and soil fertility. Functional Ecology 10: 501-511.

Verdú, M. \& García-Fayos, P. 1996. Nucleation processes in a Mediterranean bird-dispersed plant. Functional Ecology 10: 275-280.

Villar, R., Ruíz-Robleto, J., Quero, J.L., Poorter, H., Valladares, F. \& Marañón, T. 2008. Tasas de crecimiento en especies leñosas: aspectos funcionales e implicaciones ecológicas. In: Valladares, F. (eds.) Ecología del bosque mediterráneo en un mundo cambiante. pp. 193-230. Ministerio de Medio Ambiente. Organismo Autónomo Parques Nacionales, Madrid, ES.

Villar-Salvador, P., Planelles, R., Enriquez, E. \& Peñuelas, J. 2004. Nursery cultivation regimes, plant functional attributes, and field performance relationships in the Mediterranean oak Quercus ilex L. Forest Ecology and Management 196: 257-266.

Walters, M.B. \& Reich, P.B. 2000. Seed size, nitrogen supply, and growth rate affect tree seedling survival in deep shade. Ecology 81: 1887-1901.
Wright, I.J., Reich, P.B., Westoby, M., Ackerly, D.D., Baruch, Z., Bongers, F., Cavender-Bares, A., Chapin, F.S., Cornelissen, J.H.C., Dienner, M., Flexas, J., Garnier, E., Groom, P.K., Gulias, J., Hikosaka, K., Lamont, B.B., Lee, T., Lee, W., Lusk, C., Midgley, J.J., Navas, M.L., Niinemets, Ü., Oleksyn, J., Osada, N., Poorter, H., Poot, P., Prior, L., Pyankov, V.I., Roumet, C., Thomas, C.S., Tjoelker, M.G., Veneklaas, E.J. \& Villar, R. 2004. The world-wide leaf economics spectrum. Nature 428: 821-827.

Zavala, M.A., Espelta, J.M. \& Retana, J. 2000. Constraints and tradeoffs in Mediterranean plant communities: the case of holm oak (Quercus ilex L.) Aleppo pine (Pinus halepensis Mill.). Botanical Review 66: 119-149.

\section{Supporting Information}

Additional Supporting Information may be found in the online version of this article:

Appendix S1. Equations of the different functions fitted in the models calibrated for this study.

Appendix S2. Estimates of equation parameters (a, b, c, d) and associated two-likelihood unit support intervals (in brackets) for the best supported first-year growth models shown in Table 3. Functional forms (FF): LIN, Linear; EXP, Exponential; MM, Michaelis-Menten; NULL, Null model.

Appendix S3. Estimates of equation parameters (a, b, c, d) and associated two-likelihood unit support intervals (in brackets) for the best supported secondyear growth models shown in Table 5. Functional forms (FF): LIN, Linear; EXP, Exponential; MM, Michaelis-Menten; NULL, Null model.

Please note: Blackwell Publishing are not responsible for the content or functionality of any supporting materials supplied by the authors. Any queries (other than missing material) should be directed to the corresponding author for the article.

Received 24 July 2009; Accepted 7 December 2009. Co-ordinating Editor: Dr. Lindsay Turnbull. 


\section{Supporting information}

2 Appendix 1. Equations of the different functions fitted in the models calibrated for this study.

3

4 Appendix 2. Estimates of equation parameters (a, b, c, d) and associated 2-likelihood-unit

5 support intervals (in brackets) for the best-supported 1st-year growth models shown in Table 3.

6 Functional forms (FF): LIN, Linear; EXP, Exponential; MM, Michaelis-Menten; NULL, Null model.

7

8 Appendix 3. Estimates of equation parameters (a, b, c, d) and associated 2-likelihood-unit

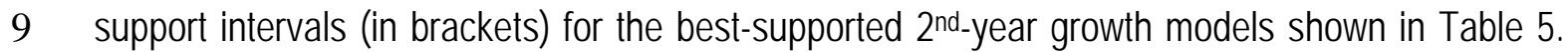

10 Functional forms (FF): LIN, Linear; EXP, Exponential; MM, Michaelis-Menten; NULL, Null model.

11

12

13

14

15

16

17

18

19

20

21

22

23

24

25 


\section{Appendix 1.}

2 [i] Linear aditive: $a+$ bFactor $_{i}+$ FFactor $_{i}+$ dFactor $_{i}$;

3 [ii] Linear multiplicative: $a+$ bFactor $_{i}{ }^{*}{ }_{c}$ Factor $B_{i}{ }^{*}$ dFactor $C_{i}$;

4 [iii] Exponential aditive: ae (bFactorA $_{i+}$ CFactorB $_{i}+$ dFactorC $\left._{i}\right)$;

5 [iii] Exponential multiplicative: ae ${\left.\text { (bFactor } A_{i}{ }^{\star} \text { FactorB }_{i}{ }^{*} \text { dFactor }_{i}\right)}_{\text {; }}$

6 [iii] Michaelis- Menten multiplicative:

7

$$
\frac{\text { aFactor }_{i}{ }^{*} \text { FactorB }_{i}}{\left(\frac{a}{b}+\text { Factor }_{i}\right) *\left(\frac{a}{c}+\text { FactorB }_{i}\right) *\left(\frac{a}{d}+\text { Factor }_{i}\right)}
$$

8

9 where $a, b, c$ and $d$ are parameter estimates that maximized the likelihood function, and Factors 


\section{Appendix 2.}

\begin{tabular}{|c|c|c|c|c|c|c|c|}
\hline Species & Growth variable & Predictors & $\mathrm{FF}$ & a & b & c & d \\
\hline \multirow[t]{20}{*}{ Q. canariensis } & \multirow[t]{2}{*}{ Total abov. biomass } & \multirow[t]{2}{*}{ Seed mass } & LIN & $\begin{array}{c}8.12 \\
{[4.39-11.61]}\end{array}$ & $\begin{array}{c}8.52 \\
{[7.67-9.38]}\end{array}$ & & \\
\hline & & & NULL & $\begin{array}{c}44.48 \\
{[39.58-49.37]}\end{array}$ & & & \\
\hline & \multirow[t]{2}{*}{$\mathrm{RGR}_{\mathrm{a}}$} & \multirow[t]{2}{*}{ Seed mass } & LIN & $\begin{array}{c}2.72 \\
{[1.12-4.38]}\end{array}$ & $\begin{array}{c}1.84 \\
{[1.48-2.23]}\end{array}$ & & \\
\hline & & & NULL & $\begin{array}{c}10.63 \\
{[8.93-12.43]}\end{array}$ & & & \\
\hline & \multirow[t]{2}{*}{$\mathrm{NAR}_{\mathrm{a}}$} & \multirow[t]{2}{*}{ Seed massxMaximum VWc } & мм & $\begin{array}{c}4999.35 \\
{[3699.76-5000]}\end{array}$ & $\begin{array}{c}94.34 \\
{[77.52-112.26]}\end{array}$ & $\begin{array}{c}54.62 \\
{[41.73-69.97]}\end{array}$ & \\
\hline & & & NULL & $\begin{array}{c}118.91 \\
\text { [95.13-142.69] }\end{array}$ & & & \\
\hline & \multirow[t]{2}{*}{$\operatorname{LAR}_{\mathrm{a}}$} & \multirow[t]{2}{*}{ Seed mass+R:FR } & EXP & $\begin{array}{c}138.33 \\
{[130.03-146.63]}\end{array}$ & $\begin{array}{c}-0.05 \\
{[-0.06 \text { to }-0.04]}\end{array}$ & $\begin{array}{c}-0.29 \\
{[-0.39 \text { to }-0.21]}\end{array}$ & \\
\hline & & & NULL & $\begin{array}{c}95.50 \\
{[88.82-102.19]}\end{array}$ & & & \\
\hline & \multirow[t]{3}{*}{$\mathrm{LMF}_{\mathrm{a}}$} & GSF & мм & $\begin{array}{c}69.46 \\
{[64.60-74.32]}\end{array}$ & $\begin{array}{c}13.15 \\
{[10.52-17.12]}\end{array}$ & & \\
\hline & & \multirow[t]{2}{*}{$R: F R+M a x i m u n ~ V W C$} & LIN & $\begin{array}{c}53.99 \\
{[50.75-57.23]}\end{array}$ & $\begin{array}{c}17.42 \\
{[12.71-21.77]}\end{array}$ & $\begin{array}{c}-0.23 \\
{[-0.29 \text { to }-0.17]}\end{array}$ & \\
\hline & & & NULL & $\begin{array}{c}53.36 \\
{[49.62-57.09]}\end{array}$ & & & \\
\hline & \multirow[t]{2}{*}{ Total leaf area } & \multirow[t]{2}{*}{ Seed mass+Superficial compaction } & LIN & $\begin{array}{c}26.29 \\
{[23.40-29.45]}\end{array}$ & $\begin{array}{c}6.01 \\
{[5.35-6.73]}\end{array}$ & $\begin{array}{c}-5.63 \\
{[-6.90 \text { to }-4.24]}\end{array}$ & \\
\hline & & & NULL & $\begin{array}{c}606.40 \\
{[545.76-668.21]}\end{array}$ & & & \\
\hline & \multirow[t]{3}{*}{$\mathrm{N}$ leaves } & Seed mass+Superficial compaction & EXP & $\begin{array}{c}4.45 \\
{[3.96-4.98]}\end{array}$ & $\begin{array}{c}0.15 \\
{[0.12-0.17]}\end{array}$ & $\begin{array}{c}-0.17 \\
{[-0.23 \text { to }-0.12]}\end{array}$ & \\
\hline & & \multirow[t]{2}{*}{ Seed massxSoil depth } & EXP & $\begin{array}{c}3.71 \\
{[3.30-4.15]}\end{array}$ & $\begin{array}{c}1.10 \\
{[0.87-1.32]}\end{array}$ & $\begin{array}{c}0.003 \\
{[0.002-0.003]}\end{array}$ & \\
\hline & & & NULL & $\begin{array}{c}5.98 \\
{[5.32-6.70]}\end{array}$ & & & \\
\hline & \multirow[t]{2}{*}{ Stem height } & \multirow[t]{2}{*}{ Seed mass+Superficial compaction+GSF } & LIN & $\begin{array}{c}117.3 \\
{[109.09-125.51]}\end{array}$ & $\begin{array}{c}8.99 \\
{[7.19-10.79]}\end{array}$ & $\begin{array}{c}-14.46 \\
{[-17.88 \text { to }-10.91]}\end{array}$ & $\begin{array}{c}-0.61 \\
{[-0.86 \text { to }-0.35]}\end{array}$ \\
\hline & & & NULL & $\begin{array}{l}111.65 \\
{[101.60-121.70}\end{array}$ & & & \\
\hline & SSL & Seed mass+NT+Maximum VWC & LIN & $\begin{array}{c}{[101.60-121.10]} \\
917.06 \\
{[860.38-966.04]}\end{array}$ & $\begin{array}{c}-68.13 \\
{[-79.36 \text { to }-59.03]}\end{array}$ & $\begin{array}{c}489.19 \\
{[360.27-601.14]}\end{array}$ & $\begin{array}{c}-4.12 \\
{[-5.170-3.311]}\end{array}$ \\
\hline & & & NULL & $\begin{array}{c}606.4 \\
{[545.76-668.21]}\end{array}$ & & & \\
\hline Q. pyrenaica & Total abov. biomass & Seed mass & EXP & $\begin{array}{c}18.38 \\
{[16.91-19.86]}\end{array}$ & $\begin{array}{l}0.09 \\
0.08-0.11]\end{array}$ & & \\
\hline & & & NULL & $\begin{array}{c}{[10.91-10.50]} \\
30.5 \\
{[27.75-32.94]}\end{array}$ & & & \\
\hline & $\mathrm{RGR}_{\mathrm{a}}$ & Seed mass+R:FR & LIN & $\begin{array}{c}3.7 \\
{[0.85-6.59]}\end{array}$ & $\begin{array}{c}3.22 \\
{[2.68-3.77]}\end{array}$ & $\begin{array}{c}-13.12 \\
{[-17.09 \text { to }-9.4]}\end{array}$ & \\
\hline & & & NULL & $\begin{array}{l}12.26 \\
{[8.71-15.82]}\end{array}$ & & & \\
\hline & & & & $\begin{array}{l}{[8.11-15.82]} \\
40.49\end{array}$ & 0.32 & -1.25 & \\
\hline & $\mathrm{NAR}_{\mathrm{a}}$ & Seed masstR:FR & EXP & {$[32.39-49.4]$} & {$[0.29-0.35]$} & {$[-1.8$ to -0.83$]$} & \\
\hline & & & NULL & $\begin{array}{c}125.02 \\
{[85.02-165.02]}\end{array}$ & & & \\
\hline & $\operatorname{LAR}_{\mathrm{a}}$ & $\mathrm{pH}$ & LIN & $\begin{array}{c}166.06 \\
{[161.08-171.05]}\end{array}$ & $\begin{array}{c}-9.76 \\
{[-10.42 \text { to }-9.12]}\end{array}$ & & \\
\hline & & & NULL & $\begin{array}{c}108.26 \\
{[103.93-112.59]}\end{array}$ & & & \\
\hline & $\mathrm{LMF}_{\mathrm{a}}$ & $\mathrm{pH}+\mathrm{R}: F \mathrm{R}$ & LIN & $\begin{array}{c}111.48 \\
{[108.14-114.83]}\end{array}$ & $\begin{array}{c}-9.68 \\
{[-10.09 \text { to }-9.28]}\end{array}$ & $\begin{array}{c}20.14 \\
{[16.69-23.36]}\end{array}$ & \\
\hline & & & NULL & $\begin{array}{c}67.26 \\
{[63.23-71.3]}\end{array}$ & & & \\
\hline & Total leaf area & Seed mass $+\mathrm{pH}$ & & 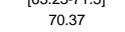 & 2.76 & -8.77 & \\
\hline & Total leaf area & Seed mass +pH & LIN & [67.56-73.18] & {$[2.29-3.22]$} & {$[-9.18$ to -8.35$]$} & \\
\hline & & & NULL & $\begin{array}{c}33.07 \\
{[30.09-36.05]}\end{array}$ & & & \\
\hline & $\mathrm{N}$ leaves & & NULL & $\begin{array}{c}5.15 \\
{[4.48-5.87]}\end{array}$ & & & \\
\hline & Stem height & GSF & EXP & $\begin{array}{c}124.06 \\
{[112.9-135.23]}\end{array}$ & $\begin{array}{c}-0.01 \\
{[-0.02 \text { to }-0.01]}\end{array}$ & & \\
\hline & & & NULL & $\begin{array}{c}83.17 \\
{[72.36-93.99]}\end{array}$ & & & \\
\hline & SSL & GSF & EXP & $\begin{array}{c}1061.12 \\
{[988.07-1138.68]}\end{array}$ & $\begin{array}{c}-0.006 \\
{[-0.008 \text { to }-0.004]}\end{array}$ & & \\
\hline & & & NULL & $\begin{array}{c}882.55 \\
{[811.94-958.42]}\end{array}$ & & & \\
\hline Q. suber & Total abov. biomass & Seed mass & мм & $\begin{array}{c}88.91 \\
{[74.69-104.92]}\end{array}$ & $\begin{array}{c}25.86 \\
{[19.91-33.62]}\end{array}$ & & \\
\hline & & & NULL & $\begin{array}{c}51.50 \\
{[45.32-57.68]}\end{array}$ & & & \\
\hline & $\mathrm{RGR}_{\mathrm{a}}$ & R:FR & LIN & $\begin{array}{c}18.18 \\
{[16.36-20.0]}\end{array}$ & $\begin{array}{c}-9.22 \\
{[-12.17 \text { to }-6.32]}\end{array}$ & & \\
\hline & & & NULL & $\begin{array}{c}13.42 \\
{[11.41-15.44]}\end{array}$ & & & \\
\hline & $\mathrm{NAR}_{\mathrm{a}}$ & R:FR & LIN & $\begin{array}{c}179.81 \\
{[161.83-197.79]}\end{array}$ & $\begin{array}{c}-90.69 \\
{[-119.92 \text { to }-61.94]}\end{array}$ & & \\
\hline & & & NULL & $\begin{array}{c}132.96 \\
{[113.01-152.9]}\end{array}$ & & & \\
\hline & $\operatorname{LAR}_{\mathrm{a}}$ & Seed mass+R:FR+NH4 & LIN & $\begin{array}{c}127.78 \\
{[123.95-131.61]}\end{array}$ & $\begin{array}{c}-1.95 \\
{[-2.51 \text { to }-1.4]}\end{array}$ & $\begin{array}{c}-23.94 \\
{[-28.86 \text { to }-18.95]}\end{array}$ & $\begin{array}{c}1.42 \\
{[0.68-2.19]}\end{array}$ \\
\hline & & & NULL & $\begin{array}{c}109.79 \\
{[105.40-114.18]}\end{array}$ & & & \\
\hline & $\mathrm{LMF}_{\mathrm{a}}$ & GSF & LIN & $\begin{array}{c}54.00 \\
{[51.30-56.70]}\end{array}$ & $\begin{array}{c}0.42 \\
{[0.34-0.49]}\end{array}$ & & \\
\hline & & & NULL & $\begin{array}{c}64.02 \\
{[60.82-67.22]}\end{array}$ & $\begin{array}{c}11.35 \\
{[9.47-13.96]}\end{array}$ & & \\
\hline & Total leaf area & Seed mass & MM & $\begin{array}{c}84.77 \\
{[72.90-97.49]}\end{array}$ & $\begin{array}{c}35.00 \\
{[26.60-47.60]}\end{array}$ & & \\
\hline & & & NULL & $\begin{array}{c}56.04 \\
{[49.88-62.21]}\end{array}$ & & & \\
\hline & $\mathrm{N}$ leaves & GSF+Superficial compaction & EXP & $\begin{array}{c}13.92 \\
{[12.81-15.04]}\end{array}$ & $\begin{array}{c}0.007 \\
{[0.005-0.01]}\end{array}$ & $\begin{array}{c}-0.15 \\
{[-0.19 \text { to }-0.11]}\end{array}$ & \\
\hline & & & NULL & $\begin{array}{c}12.61 \\
{[11.6-13.62]}\end{array}$ & & & \\
\hline & Stem height & Seed mass+R:FR & EXP & $\begin{array}{c}166.64 \\
{[148.31-181.64]}\end{array}$ & $\begin{array}{c}0.06 \\
{[0.044-0.077]}\end{array}$ & $\begin{array}{c}-0.93 \\
{[-1.18 \text { to }-0.75]}\end{array}$ & \\
\hline & & & NULL & $\begin{array}{c}147.29 \\
{[128.14-166.44]}\end{array}$ & & & \\
\hline & SSL & & NULL & $\begin{array}{c}930.86 \\
{[865.70-1001.55]}\end{array}$ & & & \\
\hline
\end{tabular}


$1 \quad$ Appendix 3.

\begin{tabular}{|c|c|c|c|c|c|c|c|}
\hline Species & Growth variable & Predictors & $\mathrm{FF}$ & a & b & c & d \\
\hline \multirow[t]{16}{*}{ Q. canariensis } & Total abov. biomass & & NULL & $\begin{array}{c}67.1 \\
{[55.03-79.18]}\end{array}$ & & & \\
\hline & $\mathrm{RGR}_{\mathrm{a}}$ & & NULL & $\begin{array}{c}271.44 \\
{[127.57-415.15]}\end{array}$ & & & \\
\hline & $\mathrm{NAR}_{\mathrm{a}}$ & & NULL & $\begin{array}{c}3.59 \\
{[1.98-5.18]}\end{array}$ & & & \\
\hline & $\mathrm{LAR}_{\mathrm{a}}$ & & NULL & $\begin{array}{c}85.21 \\
{[76.69-93.73]}\end{array}$ & & & \\
\hline & \multirow[t]{4}{*}{$\mathrm{LMF}_{\mathrm{a}}$} & GSF & LIN & $\begin{array}{c}43.84 \\
{[38.58-49.1]}\end{array}$ & $\begin{array}{c}0.27 \\
{[0.13-0.41]}\end{array}$ & & \\
\hline & & $\mathrm{P}$ & LIN & $\begin{array}{c}57.73 \\
{[52.53-62.92]}\end{array}$ & $\begin{array}{c}-2.44 \\
{[-3.81 \text { to }-0.99]}\end{array}$ & & \\
\hline & & \multirow[t]{2}{*}{ R:FR } & LIN & $\begin{array}{c}41.43 \\
{[36.05-46.41]}\end{array}$ & $\begin{array}{c}16.32 \\
{[8.91-23.36]}\end{array}$ & & \\
\hline & & & NULL & $\begin{array}{c}51.33 \\
{[45.68-56.97]}\end{array}$ & & & \\
\hline & \multirow[t]{2}{*}{ Total leaf area } & \multirow[t]{2}{*}{ Superficial compaction } & LIN & $\begin{array}{c}86.69 \\
{[77.16-96.23]}\end{array}$ & $\begin{array}{c}-12.94 \\
{[-16.52 \text { to }-9.18]}\end{array}$ & & \\
\hline & & & NULL & $\begin{array}{c}57.4 \\
{[47.06-67.7]}\end{array}$ & & & \\
\hline & \multirow[t]{2}{*}{$\mathrm{N}$ leaves } & \multirow[t]{2}{*}{ GSF+Superficial compaction } & EXP & $\begin{array}{c}10.62 \\
{[9.34-11.89]}\end{array}$ & $\begin{array}{c}0.01 \\
{[0.01-0.02]}\end{array}$ & $\begin{array}{c}-0.32 \\
{[-0.38 \text { to }-0.27]}\end{array}$ & \\
\hline & & & NULL & $\begin{array}{c}8.44 \\
{[7.43-9.51]}\end{array}$ & & & \\
\hline & \multirow[t]{2}{*}{ Stem height } & \multirow[t]{2}{*}{ Seed mass+GSF } & EXP & $\begin{array}{c}97.45 \\
{[88.68-106.22]}\end{array}$ & $\begin{array}{c}0.15 \\
{[0.13-0.17]}\end{array}$ & $\begin{array}{c}-0.01 \\
{[-0.01 \text { to }-0.008]}\end{array}$ & \\
\hline & & & NULL & $\begin{array}{c}144.67 \\
{[127.31-162.03]}\end{array}$ & & & \\
\hline & \multirow[t]{2}{*}{ SSL } & \multirow[t]{2}{*}{ Max. compaction+Minimum VwC } & EXP & $\begin{array}{c}236.12 \\
{[212.51-258.49]}\end{array}$ & $\begin{array}{c}0.08 \\
{[0.07-0.1]}\end{array}$ & $\begin{array}{c}0.06 \\
{[0.04-0.06]}\end{array}$ & \\
\hline & & & NULL & $\begin{array}{c}593.63 \\
{[522.39-661.75]}\end{array}$ & & & \\
\hline \multirow[t]{15}{*}{ Q. pyrenaica } & \multicolumn{2}{|l|}{ Total abov. biomass } & NULL & $\begin{array}{c}37.87 \\
{[31.05-44.44]}\end{array}$ & & & \\
\hline & \multicolumn{2}{|l|}{$\mathrm{RGR}_{\mathrm{a}}$} & NULL & $\begin{array}{c}82.89 \\
{[0-264.44]}\end{array}$ & & & \\
\hline & \multicolumn{2}{|l|}{$\mathrm{NAR}_{\mathrm{a}}$} & NULL & & & & \\
\hline & \multirow[t]{5}{*}{$\operatorname{LAR}_{\mathrm{a}}$} & $P$ & EXP & $\begin{array}{c}78.44 \\
{[65.89-90.99]}\end{array}$ & $\begin{array}{c}-0.11 \\
{[-0.2 \text { to }-0.06]}\end{array}$ & & \\
\hline & & GSF & LIN & $\begin{array}{c}45.02 \\
{[35.12-54.93]}\end{array}$ & $\begin{array}{c}0.54 \\
{[0.27-0.81]}\end{array}$ & & \\
\hline & & $\mathrm{NH} 4$ & EXP & $\begin{array}{c}73.54 \\
{[61.77-85.31]}\end{array}$ & $\begin{array}{c}-0.05 \\
{[-0.1 \text { to }-0.02]}\end{array}$ & & \\
\hline & & \multirow[t]{2}{*}{ R:FR } & EXP & $\begin{array}{c}43.19 \\
{[35.84-50.09]}\end{array}$ & $\begin{array}{c}0.57 \\
{[0.33-0.76]}\end{array}$ & & \\
\hline & & & NULL & $\begin{array}{c}60.17 \\
{[49.34-71]}\end{array}$ & & & \\
\hline & \multirow[t]{2}{*}{$\mathrm{LMF}_{\mathrm{a}}$} & \multirow[t]{2}{*}{ GSF } & MM & $\begin{array}{c}91.59 \\
{[70.52-116.17]}\end{array}$ & $\begin{array}{c}3.81 \\
{[2.74-5.21]}\end{array}$ & & \\
\hline & & & NULL & $\begin{array}{c}43.46 \\
{[34.77-52.15]}\end{array}$ & & & \\
\hline & Total leaf area & & NULL & $\begin{array}{c}21.32 \\
{[17.06-25.71]}\end{array}$ & & & \\
\hline & $\mathrm{N}$ leaves & & NULL & $\begin{array}{c}3.72 \\
{[3.02-4.51]}\end{array}$ & & & \\
\hline & \multirow[t]{2}{*}{ Stem height } & \multirow[t]{2}{*}{ R:FR+Superficial compaction } & EXP & $\begin{array}{c}133.92 \\
{[120.53-147.31]}\end{array}$ & $\begin{array}{c}-1.16 \\
{[-1.41 \text { to }-0.94]}\end{array}$ & $\begin{array}{c}0.28 \\
{[0.24-0.31]}\end{array}$ & \\
\hline & & & NULL & $\begin{array}{c}144.51 \\
{[114.16-174.85]}\end{array}$ & & & \\
\hline & SSL & & NULL & $\begin{array}{c}846.69 \\
{[711.22-978.95]}\end{array}$ & & & \\
\hline Q. suber & Total abov. biomass & Seed mass+GSF & LIN & $\begin{array}{c}-26.07 \\
{[-33.34 \text { to }-18.03]}\end{array}$ & $\begin{array}{c}9.09 \\
{[7.82-10.55]}\end{array}$ & $\begin{array}{c}1.08 \\
{[0.86-1.3]}\end{array}$ & \\
\hline & & & NULL & $\begin{array}{c}55.22 \\
{[41.97-68.48]}\end{array}$ & & & \\
\hline & $\mathrm{RGR}_{\mathrm{a}}$ & GSF & LIN & $\begin{array}{c}-497.41 \\
{[-657.91 \text { to }-332.9]}\end{array}$ & $\begin{array}{c}13.34 \\
{[9.31-17.42]}\end{array}$ & & \\
\hline & & R:FR & LIN & $\begin{array}{c}-648.48 \\
{[-809.52 \text { to }-481.76]}\end{array}$ & $\begin{array}{c}886.91 \\
{[662.75-1000]}\end{array}$ & & \\
\hline & & & NULL & $\begin{array}{l}5.52 \mathrm{E}-07 \\
{[0-164.35]}\end{array}$ & & & \\
\hline & $\mathrm{NAR}_{\mathrm{a}}$ & & NULL & $\begin{array}{c}3.59 \\
{[1.98-5.18]}\end{array}$ & & & \\
\hline & $\operatorname{LAR}_{a}$ & & NULL & $\begin{array}{c}95.51 \\
\text { [86.91-104.11] }\end{array}$ & & & \\
\hline & $\mathrm{LMF}_{\mathrm{a}}$ & GSF & MM & $\begin{array}{c}91.66 \\
\text { [82.49-101.74] }\end{array}$ & $\begin{array}{c}8.4 \\
{[6.64-10.74]}\end{array}$ & & \\
\hline & & Null & NULL & $\begin{array}{c}60.32 \\
{[53.69-66.96]}\end{array}$ & & & \\
\hline & Total leaf area & Seed mass+GSF & LIN & $\begin{array}{c}-19.7 \\
{[-27.25 \text { to }-12.43]}\end{array}$ & $\begin{array}{c}7.49 \\
{[6.14-8.76]}\end{array}$ & $\begin{array}{c}1.06 \\
{[0.85-1.27]}\end{array}$ & \\
\hline & & & NULL & $\begin{array}{c}51.69 \\
{[39.29-64.1]}\end{array}$ & & & \\
\hline & $\mathrm{N}$ leaves & GSF & EXP & $\begin{array}{c}6.28 \\
{[5.65-6.91]}\end{array}$ & $\begin{array}{c}0.023 \\
{[0.021-0.024]}\end{array}$ & & \\
\hline & & & NULL & $\begin{array}{c}14.3 \\
{[12.87-15.73]}\end{array}$ & & & \\
\hline & Stem height & Seed mass+R:FR & EXP & $\begin{array}{c}132.57 \\
{[117.99-145.83]}\end{array}$ & $\begin{array}{c}0.12 \\
{[0.10-0.13]}\end{array}$ & $\begin{array}{c}-0.79 \\
{[-1 \text { to }-0.6]}\end{array}$ & \\
\hline & & & NULL & $\begin{array}{c}170.06 \\
{[137.75-200.67]}\end{array}$ & & & \\
\hline & SSL & Seed mass+R:FR & LIN & $\begin{array}{c}2169.89 \\
\text { [2017.99-2304.79] }\end{array}$ & $\begin{array}{c}-108.24 \\
{[-130.97 \text { to }-87.21]}\end{array}$ & $\begin{array}{c}-916.82 \\
{[-1102.19 \text { to }-739.95]}\end{array}$ & \\
\hline & & & NULL & $\begin{array}{l}1015.57 \\
{[822.61-1202.921}\end{array}$ & & & \\
\hline
\end{tabular}


